\title{
High-resolution stratigraphy and the response of biota to Late Cenozoic environmental changes in the central equatorial Pacific Ocean (Manihiki Plateau)
}

\author{
H. Beiersdorf ${ }^{\text {a }}$, T. Bickert ${ }^{\text {b }}$, P. Cepek ${ }^{\text {a }}$, J. Fenner ${ }^{\text {a }}$, N. Petersen ${ }^{\text {c }}$, J. Schönfeld ${ }^{\text {d, }}$ \\ W. Weiss ${ }^{\text {a }}$, M.-Z. Won ${ }^{\mathrm{e}}$ \\ ${ }^{a}$ Bundesanstalt für Geowissenschaften und Rohstoffe, P.O. Box 510153, D-30631 Hannover, Germany \\ ${ }^{b}$ Universität Bremen, FB Geowissenschaften, D-28334 Bremen, Germany \\ ' Institut für Allgemeine und Angewandte Geophysik, Universität München, Theresienstraße 41, D-80333 München, \\ Germany \\ ${ }^{d}$ GEOMAR Forschungzentrum für marine Geowissenschaften der Universität Kiel Wischhofstraße 1-3, Geb. 4, \\ D-24148 Kiel, Germany \\ ' Department of Marine Science, College of Natural Sciences Pusan National University, Pusan, South Korea \\ Received 3 November 1994; revision accepted 1 February 1995
}

\begin{abstract}
An undisturbed $16 \mathrm{~m}$ late Pliocene-Pleistocene sediment core spanning 2.6 Myr of deposition was recovered from the Manihiki Plateau by the German research vessel Sonne in 1990. This core 34KL complements the heavily disturbed late Pliocene-Pleistocene core sections of DSDP Site 317, and is well suited for stratigraphic correlation.

The sediments consist of calcareous microfossils $\left(93-97 \% \mathrm{CaCO}_{3}\right)$, minor portions of siliceous microfossils and detrital minerals. All important calcareous microfossil zones could be identified and correlated with the magnetostratigraphic and isotope stratigraphic events, stages and periods. Due to the high degree of silica dissolution, the late Quaternary radiolarian Buccinosphaera invaginata Zone is the only siliceous fossil zone which could be identified. An interval with Globigerinoides gomitulus/pink was found within the middle Pleistocene which is clearly distinguished from the Globigerinoides ruber/pink interval of the late Pleistocene. The magnetostratigraphic Gauss-Matuyama and Matuyama-Brumhes boundaries as well as the Olduvai and Jaramillo events were clearly identified. The $\delta^{18} 0$ curve displays the $100 \mathrm{kyr}$ (Milankovitch) and the $41 \mathrm{kyr}$ (Laplace) cyclicity periods. The beginning of the Laplace Period and the last occurrence of the calcareous nannofossil Discoaster brouweri, which marks the end of the Pliocene, fall within the base of the Olduvai Event. There is also a marked drop in sedimentation rates around this time, which seems to be a regional phenomenon.

Prominent $3.5 \mathrm{kHz}$ subbottom reflectors at $8 \mathrm{~ms}$ and $15 \mathrm{~ms}$ reflection time are related to lithologic changes near the Mid-Pleistocene Revolution (MPR) and the beginning of the Laplace Period or the Pleistocene, respectively. It is possible to trace these reflectors laterally to the eroded eastern edge of the Manihiki Plateau where they can be tied to older strata.
\end{abstract}




\section{Introduction}

A central requirement for paleoceanographic studies is the recovery of continuous, undisturbed sedimentary sections which allow the establishment of high resolution stratigraphies and the study of evolution of global ocean dynamics and climate. Many good records were obtained by the Ocean Drilling Program (ODP) from the eastern equatorial Pacific Ocean (Mayer et al., 1992) and the Ontong-Java Plateau (Berger et al., 1993a,b). They come from diagenetically little affected calcareous sections which were deposited at high accumulation rates.

The Manihiki Plateau of the central Pacific Ocean, too, has a good potential to recover complete Neogene sections suitable for high-resolution studies. Because the basement of the Manihiki Plateau consists of a pile of overly thick oceanic crust rising up to $2 \mathrm{~km}$ above the surrounding crust at about $5 \mathrm{~km}$ (Hussong et al., 1979), sedimentation occurred always above the calcite compensation depth (CCD). However, so far only one plateau site was cored by scientific drilling. During Leg 33 of the Deep Sea Drilling Project (DSDP) D/V Glomar Challenger occupied Site 317 on the so-called High Plateau (the eastern sub-plateau of the Manihiki Plateau) and drilled $910 \mathrm{~m}$ of Quaternary to Cretaceous sediments (Schlanger et al., 1976). The Quaternary and Pliocene sediments are altogether $54 \mathrm{~m}$ thick and consist of calcareous oozes. The Quaternary section alone has a thickness of $9.50 \mathrm{~m}$. The youngest sediments recovered were intensely disturbed by the drilling process, and so they do not allow the establishment of a high-resolution stratigraphy or carrying out a reliable paleoceanographic study, although the preservation of microfossils is excellent and biogenic components are not diluted by other lithic components. The relatively low thickness of the Quaternary sediments results from the low surface water productivity of about $40 \mathrm{~g}$ carbon $/ \mathrm{m}^{2} /$ year (Berger et al., 1987) in the northern central part of the South Pacific gyre.

The moderate thickness of the Quaternary sediments made the DSDP site attractive for resampling by conventional piston coring in order to obtain an undisturbed Quaternary sediment sequence and a good portion of unaffected Pliocene sediments as well. Therefore, in 1990, during Cruise SO 67-1 of the German R/V Sonne, a piston corer was deployed at location $34 \mathrm{KL}\left(11^{\circ} 00.1^{\prime} \mathrm{S}\right.$, $162^{\circ} 15.8^{\prime} \mathrm{W}$ ) in a water depth of $2612 \mathrm{~m}$ close to DSDP Site 317 (Fig. 1), with $16.40 \mathrm{~m}$ of undisturbed Quaternary and Pliocene calcareous ooze being recovered.

This article presents the results of detailed biostratigraphic studies as well as oxygen and carbon isotope stratigraphic and magnetostratigraphic analyses. An acoustostratigraphic correlation is proposed also.

\section{Methods}

\subsection{Navigation and underwater acoustics}

For positioning during cruise SO $67-1$, the Global Positioning System GPS was used together

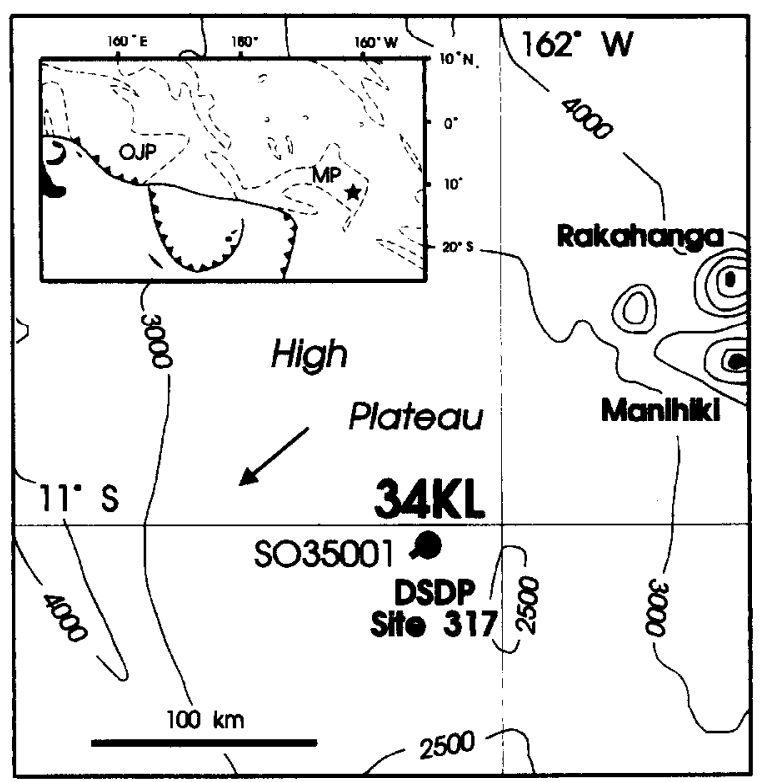

Fig. 1. Location map of core $34 \mathrm{KL}$ and $3.5 \mathrm{kHz}$ sub-bottom profile SO 35001 from the Manihiki Plateau, Pacific Ocean. Note: Location $34 \mathrm{KL}$ is very close to Site 317 of the Deep Sea Drilling Project (DSDP). Depth contours in metres. Arrow: Surface current direction observed during $\mathrm{R} / \mathrm{V}$ Sonne cruises 1984 and 1990. Inset: $M P=$ Manihiki Plateau; $O J P=$ Ontong-Java Plateau; dashed line $=4500 \mathrm{~m}$ countour; solid = plate boundaries; asterisk = location $34 \mathrm{KL}$. 


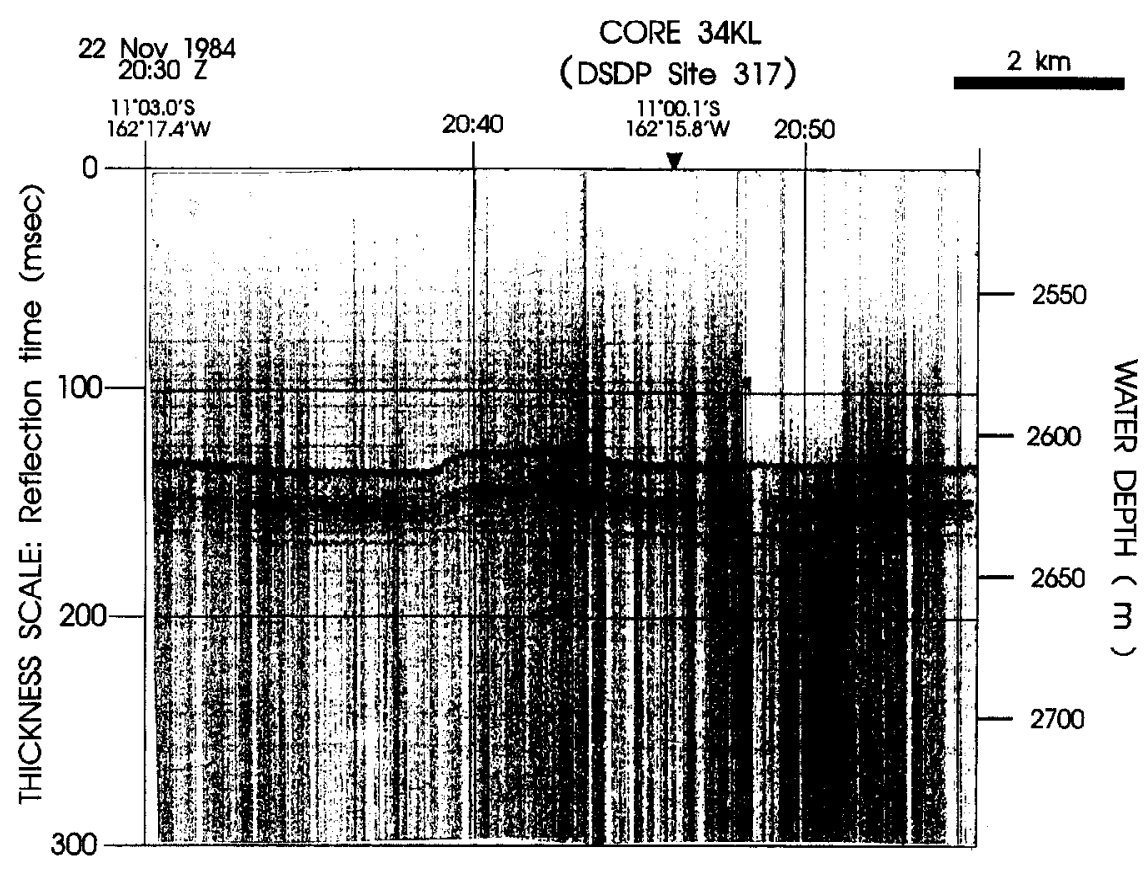

Fig. 2. $3.5 \mathrm{kHz}$ echogram SO 35001 across core location 34KL, resp. DSDP Site 317.

with the transit satellite navigation system TRANSIT SATNAV. The $3.5 \mathrm{kHz}$ echograms SO 35001 and SO 67065 (Figs. 2 and 3) across DSDP

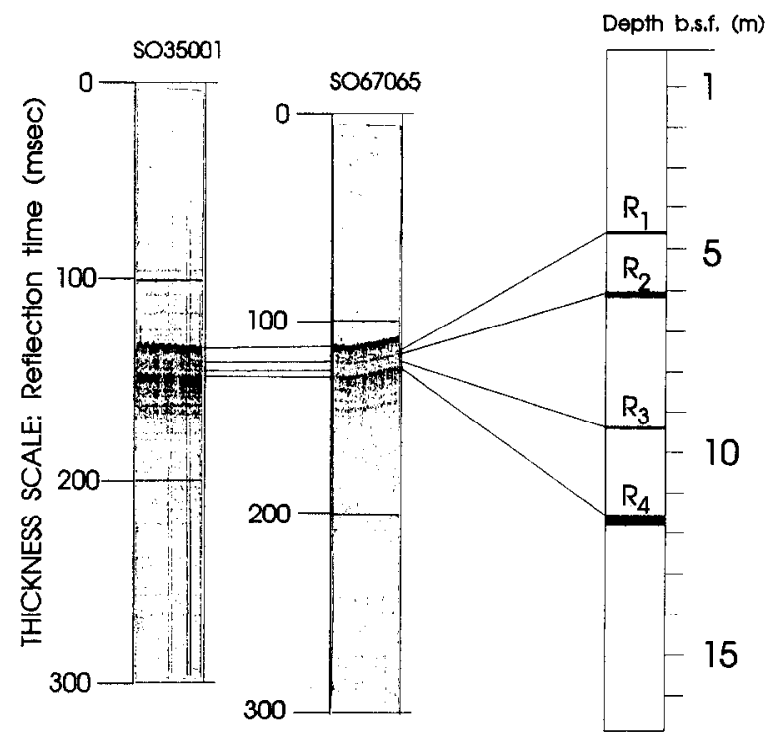

Fig. 3. Depth of $3.5 \mathrm{kHz}$ subbottom reflectors with their relative strengths (amplitude) of profile SO 35001 and SO 67065 based on sound velocity estimates $\left(1500 \mathrm{~m} / \mathrm{s}\right.$ for $R_{1}$ and $\mathrm{R}_{2} ; 1550 \mathrm{~m} / \mathrm{s}$ for $\mathrm{R}_{3}$ and $\mathrm{R}_{4}$ ).
Site 317 and the location 34KL, respectively, were obtained by a hull-mounted $3.5 \mathrm{kHz}$ subbottom profiler (O.R.E. series 1036-model 140).

\subsection{Sampling, core description and $\mathrm{CaCO}_{3}$ determination}

A conventional $20.50 \mathrm{~m}$ piston corer (core diameter: $8.5 \mathrm{~cm}$ ) was used to recover the sediments at the location $34 \mathrm{KL}$. The sediments were recovered in four successive $5 \mathrm{~m}$ plastic liners. A split piston was used to avoid both suction within the barrels and core disturbance while the corer penetrated the sediments. During handling on deck, the very water-rich $20 \mathrm{~cm}$ at the top sediment of the core was remoulded. No visible core disturbance occurred for the remaining $16.20 \mathrm{~m}$ of core $34 \mathrm{KL}$. Sediment colours were determined according to the Munsell Soil Color Charts (1975). The calcium carbonate $\left(\mathrm{CaCO}_{3}\right)$ content was obtained from samples taken at intervals of about $50 \mathrm{~cm}$ downcore. Quadruple analyses of calcium carbonate were made by volumetric titration.

For the determination of the sediment composition, smear slides were analyzed from micro- 
samples taken every meter and where special lithologic changes were observed. Clinoptilolite was determined during the counting of siliceous microfossils at a magnification of $1000 \times$ under the microscope. These analyses permitted determination of this mineral far beyond the detection limit of XRD analysis.

\subsection{Magnetostratigraphy}

The intensity of the natural remanent magnetization (NRM) was determined by using a cryogenic magnetometer Type LETI Remanometre RS 01 . Several pilot samples were demagnetized stepwise in an alternating magnetic field. A stable primary component of natural remanent magnetization was defined by an alternating field demagnetization in 200 Oe. Therefore, this field was applied to all remaining samples.

Since the core was not oriented, only the inclination could be used to establish a polarity sequence. Given the core location at $10^{\circ} \mathrm{S}$, an inclination of $-21^{\circ}$ was assumed. The biostratigraphic evidence indicated that the uppermost core section was magnetized under the present magnetic field, permitting the reorientation of the azimuth of the core and so enabling the use of both inclination and declination to establish the magnetostratigraphy for core $34 \mathrm{KL}$. In addition to the magnetostratigraphic determinations, the hysteresis loops were established for 17 samples. These samples were taken at equal intervals down-core.

\subsection{Isotope stratigraphy}

For oxygen and carbon stable-isotopic analyses, 317 subsamples were taken in $5 \mathrm{~cm}$ intervals. They were washed on a $63 \mu \mathrm{m}$ sieve and dried. Twenty specimens of the planktonic foraminifer Globigerinoides sacculifer were picked from the 355 to $425 \mu \mathrm{m}$ grain-size fraction. The rather narrow size fraction was chosen to minimize the influence of vital effects on the isotopic ratios. An effort was made to avoid immature members of Globigerinoides fistulosus by selecting only intact $G$. sacculifer individuals with a sacciform final chamber. Sixty to $80 \mu \mathrm{g}$ of the crushed specimens were used for isotopic measurements. The analyses were performed using a Finnigan MAT 251 micromass-spectrometer coupled with a Finnigan automated carbonate device at the University of Bremen. The carbonate was reacted with orthophosphoric acid at $75^{\circ} \mathrm{C}$. The reproducibility of the measurements, as referred to an internal carbonate standard (Solnhofen limestone), is $\pm 0.07 \%$ and $\pm 0.05 \%$ o $(1 \sigma$-value over a one year period $)$ for oxygen and carbon isotopes, respectively. The conversion to the PDB scale was performed using the international standards NBS 18, 19 and 20.

We applied the oxygen isotope stratigraphy as a chronostratigraphic tool to determine the ages of biostratigraphic events and to calculate the accumulation rates. The oxygen isotope events of core $34 \mathrm{KL}$ were visually linked to the SPECMAPstack for the first $630 \mathrm{kyr}$ (Imbrie et al., 1984), and to the eastern Pacific planktonic record of ODP Site 677 (Shackleton et al., 1990) for the older part down to $2.6 \mathrm{Ma}$. The age model of the latter site was obtained by tuning the isotopic signal to the obliquity and precession frequency bands of earth insolation and was found to be consistent with revised ${ }^{40} \mathrm{Ar} /{ }^{39} \mathrm{Ar}$ datings of paleomagnetic reversals (Baksi, 1992; Cande and Kent, 1992; Izett and Obradovitch, 1991).

Accumulation rates were calculated by using the equation (Van Andel et al., 1975):

$A R=L S R \times D D$

where $A R$ is the accumulation rate in $\mathrm{g} / \mathrm{cm}^{2} / 1000$ years, $L S R$ is the linear sedimentation rate in $\mathrm{cm} / 1000$ years and $D D$ is the dry bulk density in $\mathrm{g} / \mathrm{cm}^{3}$. The density values were calculated as mean values for each core interval between two age control points. They were obtained from volume-defined samples following Boyce (1976).

\subsection{Micropaleontological investigations}

\subsubsection{Siliceous fossils}

Moderately preserved siliceous shells and skeletons of diatoms and radiolaria are present in the upper $2.20 \mathrm{~m}$ of the core. The sampling interval is $3-5 \mathrm{~cm}$. Below $2.20 \mathrm{~m}$ the sampling interval was usually $20-30 \mathrm{~cm}$.

Samples were prepared quantitatively following Fenner $(1982,1985)$. To prepare slides for the 
investigation of radiolaria a homogeneous suspension of the $\mathrm{HCl}$ - and $\mathrm{H}_{2} \mathrm{O}_{2}$-insoluble residue $>40 \mu \mathrm{m}$ of a sample was poured into a settling vessel built following Battarbee (1973). The mounting medium used is hyrax (refractive index n.d. $=1.71$; solvent toluene).

Species identification and counting of diatoms was made at a magnification of $1000 \times$ using an oil immersion objective (Leitz PL APO Oel 100/1.32). For radiolaria, a working magnification of $100-450 \times$ was used (Leitz objectives PL FL 10/0.30, PL APO 25/0.65, PL APO 40/0.75).

\subsubsection{Calcareous nannofossils}

Twenty-nine samples were analysed for calcareous nannofossils. Slides were prepared using the decantation method of Hay (1965) and Cepek (1981). Microscopic examination was made with a Zeiss Photomicroscope III (ocular: $12.5 \times$ magnification changer: $1.25 \times$; objective: $100 \times$ with phase contrast), and using a CamScan CS2 scanning electron microscope.

\subsubsection{Benthic foraminifers}

Ninety-one volume-defined samples were obtained using syringes. The samples were washed on a $63 \mu \mathrm{m}$ sieve, the residues dried and split into two aliquots for benthic and planktonic foraminifers. Benthic foraminifers were studied from the $250-2000 \mu \mathrm{m}$ grain-size fraction of 59 selected samples. This size fraction was chosen because of the need to eliminate smaller forms which are often displaced by redeposition (Lohmann, 1978; Lutze and Coulbourn, 1984). All benthic foraminifers were selected from the sample, sorted to species level, and mounted on Plummer slides, and finally counted. The total number of tests varies from 37 to 167 specimens per sample.

\subsubsection{Planktonic foraminifers}

A total of $1093-5 \mathrm{~cm}^{2}$ samples taken at $10-20 \mathrm{~cm}$ intervals were used. The samples were washed on a $63 \mu \mathrm{m}$ sieve. The remaining fraction was dried at $50^{\circ} \mathrm{C}$, weighed and dry-sieved into fractions ( $>315 \mu \mathrm{m}, 315-200 \mu \mathrm{m}$ and $200-63 \mu \mathrm{m}$ ). At least 500 specimens from each fraction were picked and identified. Census data of selected species are presented graphically in Fig. 13. Species counts were made on splits of the $>200 \mu \mathrm{m}$ grainsize fraction containing approximately 300 and commonly more specimens.

We have followed the illustrations and taxonomy of Parker (1962, 1967), Bé (1977), Saito et al. (1981), and Kennett and Srinivasan (1983) for identification of planktonic taxa. The planktonic foraminiferal biostratigraphic scheme used here is generally based on that of Blow (1969) and Bolli and Saunders (1985) with modifications given by Chapronière (1991) for the Late Pliocene and the Pleistocene.

\section{Results}

\subsection{Underwater acoustics}

Both the seismic reflection profiles used for the selection of DSDP Site 317 and the subbottom profiler records obtained by $\mathrm{R} / \mathrm{V}$ Sonne show a uniform echo-character over distances of several kilometres for the upper $700 \mathrm{~ms}$ reflection time (Schlanger and Winterer, 1976; Fig. 2). The apparent lack of angular unconformities suggests that no major erosion events have occurred on the High Plateau of the Manihiki Plateau since the Miocene.

The $3.5 \mathrm{kHz}$ subbottom profiler records $\mathrm{SO}$ 67065 of R/V Sonne Cruise SO 67-1 supplemented with these from SO 35001 of an earlier Cruise SO 35-1 by the same vessel in 1984 (Beiersdorf and Erzinger, 1989; Fig. 3), across DSDP Site 317 show a more or less identical acoustic stratigraphy, charactcrized by densely spaced reflectors. The deepest subbottom reflector is $33 \mathrm{~ms}$ (reflection time) below the sea floor reflector and is as weak as reflectors at $6\left(R_{1}\right), 12\left(R_{3}\right), 20$, and $23 \mathrm{~ms}$ reflection times. A reflector at $8 \mathrm{~ms}\left(R_{2}\right)$ is somewhat stronger. The strongest reflector occurs at 15 $\mathrm{ms}\left(\mathrm{R}_{4}\right)$.

The only strong impedance contrasts in the subbottom profiler records are below the $15 \mathrm{msec}$ reflector, where layering is more pronounced. The zone above this reffector band is acoustically more transparent. 


\subsection{Lithology}

The lithologic characteristics of core $34 \mathrm{KL}$ are presented in Fig. 4. Below the remoulded uppermost $20 \mathrm{~cm}$ of sediments, well preserved bioturbation features indicate that the remainder of the core has not been recognizably deformed by the coring process, and is well suited for highresolution stratigraphic and paleoenvironmental studies.

The sediments are nannofossil-foraminiferal to foraminiferal-nannofossil oozes. Calcite stemming from the calcareous microfossils is the major component with values ranging from 93.2 to $98.8 \%$ calcium carbonate. The siliceous fossil fraction is restricted to the uppermost $3 \mathrm{~m}$ and is made up mainly by diatoms and radiolarians, while sponge spicules, silicoflagellates and archaeomonadacea are very rare. The siliceous fraction rarely exceeds $4.5 \%$, but never $6 \%$.

The only significant non-biogenic components were traces of clinoptilolite, quartz and feldspar, all of them were recognized microscopically.

Color changes are gradational, but occur within intervals of only few centimeters. Based on the dominant colors, the sediment column is subdivided into three units:

Unit 1 from top to $1.60 \mathrm{~m}$ sub-bottom is light yellowish-brown,

Unit 2 from 1.60 to $11.80 \mathrm{~m}$ is very palebrown, and

Unit 3 from 11.80 to $16.20 \mathrm{~m}$ is white.

Sedimentary structures are exclusively burrows, among which Zoophycos is the most common.

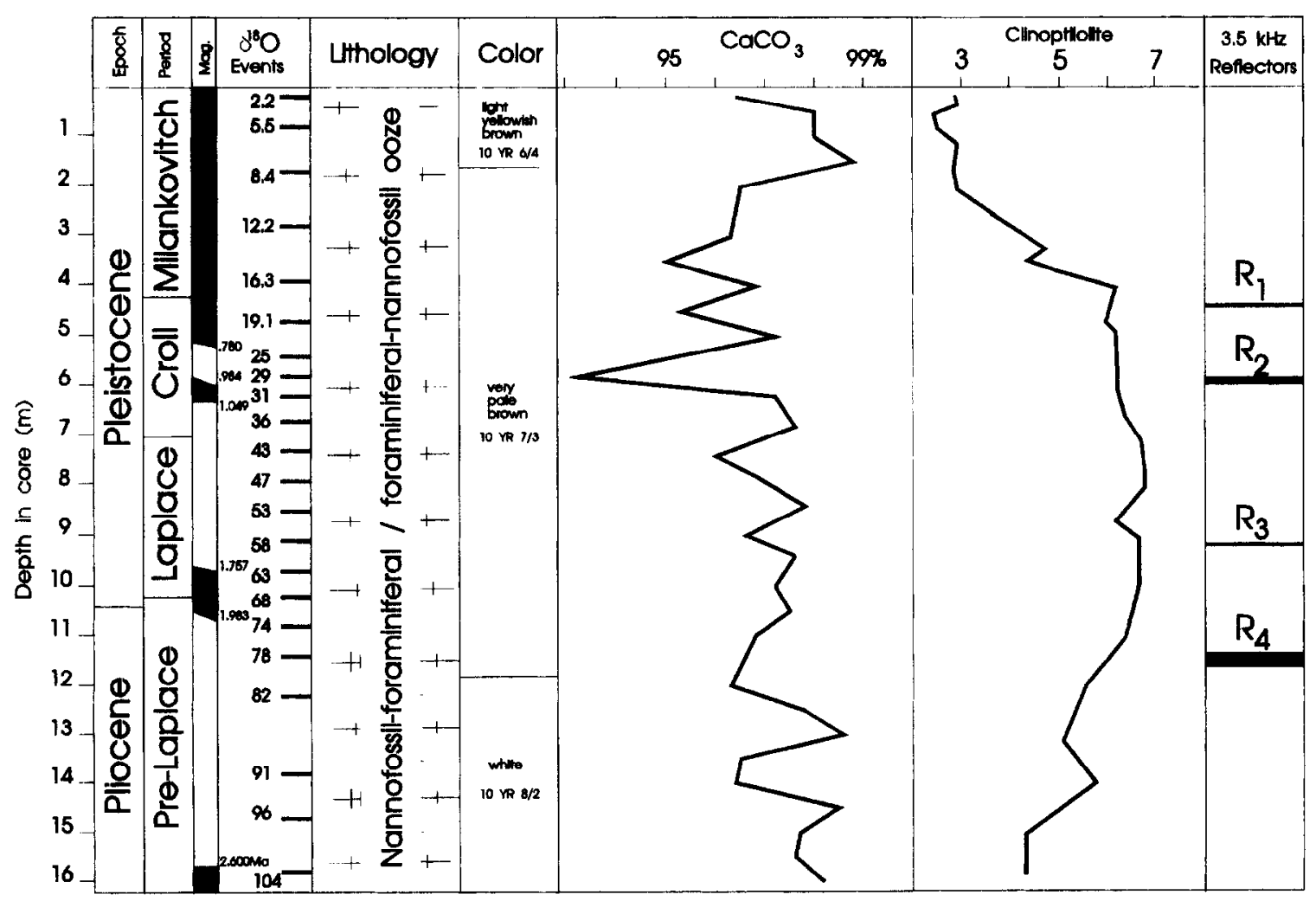

Fig. 4. Lithostratigraphic and magnetostratigraphic summary of core $34 \mathrm{KL}$ with $\delta^{18} \mathrm{O}$-events and $3.5 \mathrm{kHz}$ acoustic reflectors. Numbers at magnetostratigraphic boundaries are ages (Ma) according to Cande and Kent (1992). Normally magnetized sections are presented in black. Clinoptilolite is presented as log no. of crystals per gram sediment (for details, see Fig. 9). 


\subsection{Magnetostratigraphy}

The intensity of the natural remanent magnetization (NRM) was of the order of $10^{-7}$ Gauss for all of the samples. Despite these low intensities, a magnetostratigraphy of high accuracy has been established with magnetostratigraphic boundaries at six levels (Table 1; Fig. 5).

Besides these standard stratigraphic boundaries, additional short events of reversed magnetization were observed in the core (Fig. 5). It cannot be proven, however, whether these events represent actual geomagnetic field reversals.

Fig. 6 displays an example of hysteresis loops, with typically low magnetization intensities. Negative slopes of the curve occur when strong magnetizing fields are applied (solid line). This results from the diamagnetic behaviour of the carbonate particles which form the dominating sediment constituents. When the diamagnetic part is subtracted, the ferrimagnetic component is clearly visible. According to the shape of the ferrimagnetic hysteresis curve, and in agreement with isothermal remanent magnetization acquisition curves (Fig. 7), the ferrimagnetic host mineral very likely is magnetite, probably represented by fossil magnetosomes of magnetotactic bacteria (Von Dobeneck, 1992).

The magnetization intensity of this ferrimagnetic hysteresis example indicates for magnetite a volume content of $3 \times 10^{-6}$. If the magnetite represents fossil magnetosomes, a single bacterium of which can carry about 30 (a figure given by Vali et al., 1987), and if these magnetosomes have an

Table 1

Magnetostratigraphy of core $34 \mathrm{KL}$ (all ages according to Cande and Kent, 1992)

\begin{tabular}{lll}
\hline $\begin{array}{l}\text { Depth in core } \\
(\mathrm{cm})\end{array}$ & $\begin{array}{l}\text { Magnetostratigraphic } \\
\text { boundary }\end{array}$ & $\begin{array}{l}\text { Age } \\
\text { (million } \\
\text { years) }\end{array}$ \\
\hline $510-520$ & Brunhes-Matuyama & 0.780 \\
$580-600$ & Top Jaramillo & 0.984 \\
630 & Base Jaramillo? & 1.049 \\
$960-970$ & Top Olduvai & 1.757 \\
$1050-1070$ & Base Olduvai & 1.983 \\
1570 & Matuyama-Gauss & 2.600 \\
\hline
\end{tabular}

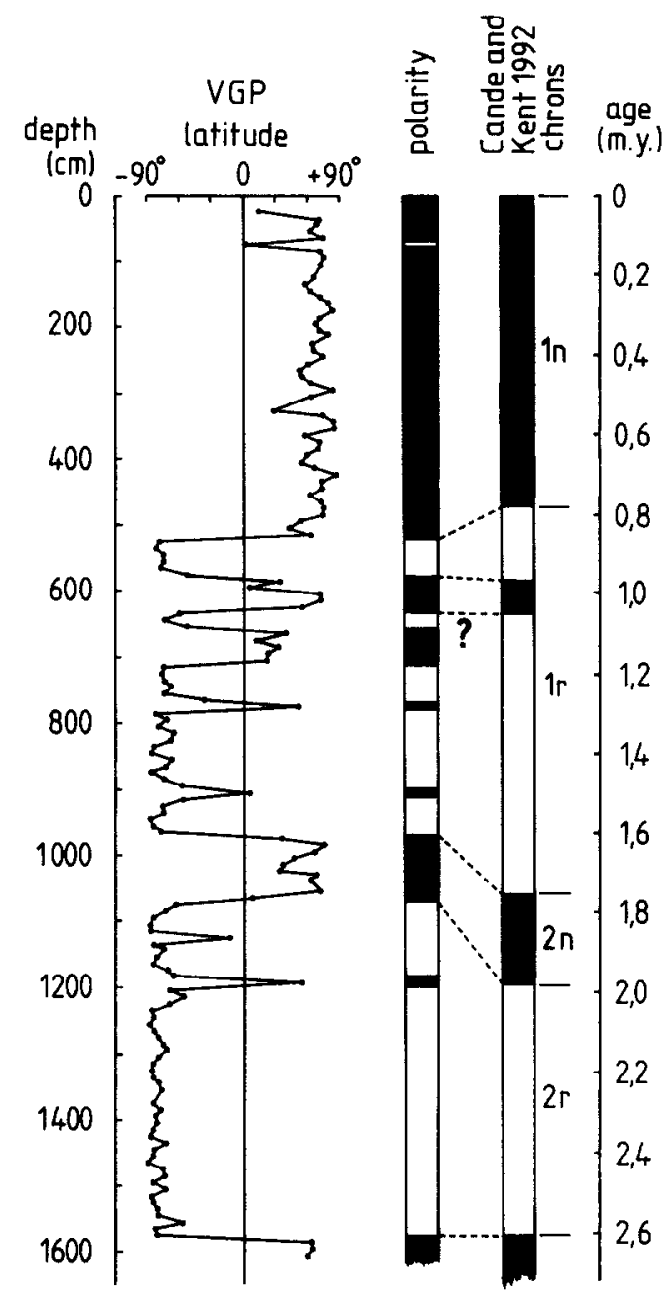

Fig. 5. Magnetostratigraphy of core $34 \mathrm{KL}$. Virtual geomagnetic pole latitude ( $V G P$ ) for each sample is computed from inclination and adjusted declination as explained in the text. At the right margin is the sequence of polarity zones based on these data. Next to it is the time scale of Cande and Kent (1992).

edge length of $100 \mathrm{~nm}$, then, approximately 100 magnetotactic bacteria have dwelled in a cubic centimeter of sediment. The significance of this is discussed below.

\subsection{Isotope stratigraphy, age control and accumulation rates}

Fig. 8 shows the oxygen and carbon isotope records of $34 \mathrm{KL}$ versus core depth. It also gives the age-depth relationship based on the graphic 


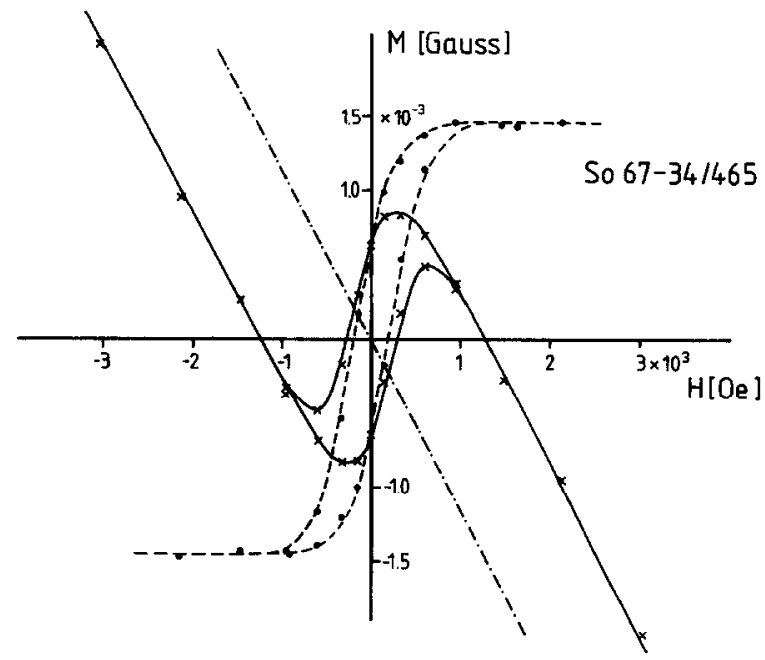

Fig. 6. Magnetic hysteresis loop of sample $34 \mathrm{KL} / 465 \mathrm{~cm}$ measured at room temperature (solid line). The magnetic behaviour of the sample is dominated by the diamagnetism of the calcareous nannofossil constituent. After subtraction of the diamagnetic contribution (dash-dotted line) the hysteresis loop of the ferrimagnetic mineral component (magnetite) is left (dashed line).

magnetization (Gauss)

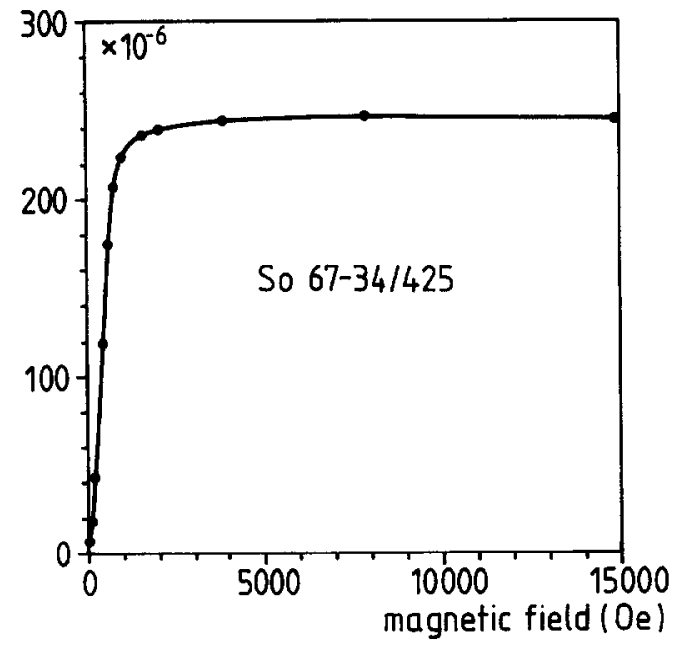

Fig. 7. Isothermal remanent magnetization (IRM) acquisition of sample $34 \mathrm{KL} / 425 \mathrm{~cm}$. Saturation of IRM is obtained in a magnetic field of 3000 Oe already, indicating magnetite as the only magnetic mineral. All the samples of core $34 \mathrm{KL}$ show almost identical curves. correlation to the $\delta^{18} 0$ record of ODP Site 677 (Shackleton et al., 1990), and the resulting accumulation rate. (The isotopic data and the age-control points as well as dry density values will be made available upon request by $\mathrm{T}$. Bickert or J. Schönfeld.)

The $\delta^{18} \mathrm{O}$-values of Globigerinoides sacculifer vary within a range of -0.5 to $-1.8 \%$. The large amplitudes in the uppermost $5.20 \mathrm{~m}$ of the core are related to the $100 \mathrm{kyr}$ glacial-interglacial cycles of the late Pleistocene.

However, the amplitudes of up to $0.8 \%$ lie clearly below the last glacial-to-interglacial ice volume effect of about $1.2 \%$ (Fairbanks, 1989), a range that is also observed in the planktonic foraminiferal isotope record of Globigerinoides sacculifer of ODP Site 806B, Ontong-Java Plateau (Berger et al., 1993a). The difference in amplitude might be caused by the smoothing effect of bioturbation on the isotope signal due to the low mean sedimentation rate of about $5.40 \mathrm{~m} / \mathrm{Myr}$ in this core interval. Mix (1987) showed that there is an increasing effect of the mixed layer on the isotope record with decreasing sedimentation rate below rates of $20 \mathrm{~m} / \mathrm{Myr}$.

At $5.20 \mathrm{~m}$ core depth, there is a step in amplitude that can be related to oxygen isotope stage $22 / 23$ boundary at about 0.9 Ma. Below this "MidPleistocene Revolution" (MPR) (Berger and Wefer, 1992), the amplitudes decrease to about $0.4 \%$, and no further $100 \mathrm{kyr}$ periods are observed in the lower part of core $34 \mathrm{KL}$. The reason for this change in amplitude which is also known from other oxygen isotope records (Berger et al., 1993a; Ruddiman et al., 1989; Shackleton et al., 1990; Tiedemann et al., 1994) may be a greater influence of continental ice dynamics combined with isostatic effects of the ice-loaded earth crust in the late Pleistocene. The short-term variations, which dominate the record from $5.20 \mathrm{~m}$ to the bottom of the core, are likely linked to obliquity cycles (41 kyr period). From the correlation of the $34 \mathrm{KL}$ oxygen isotope record to the record of ODP Site 677 (Shackleton et al., 1990), the Manihiki Plateau record is supposed to reach an age of about 2.6 $\mathrm{Ma}$ at $15.88 \mathrm{~m}$ near the bottom of the core, which is consistent with the paleomagnetic Matuyama- 


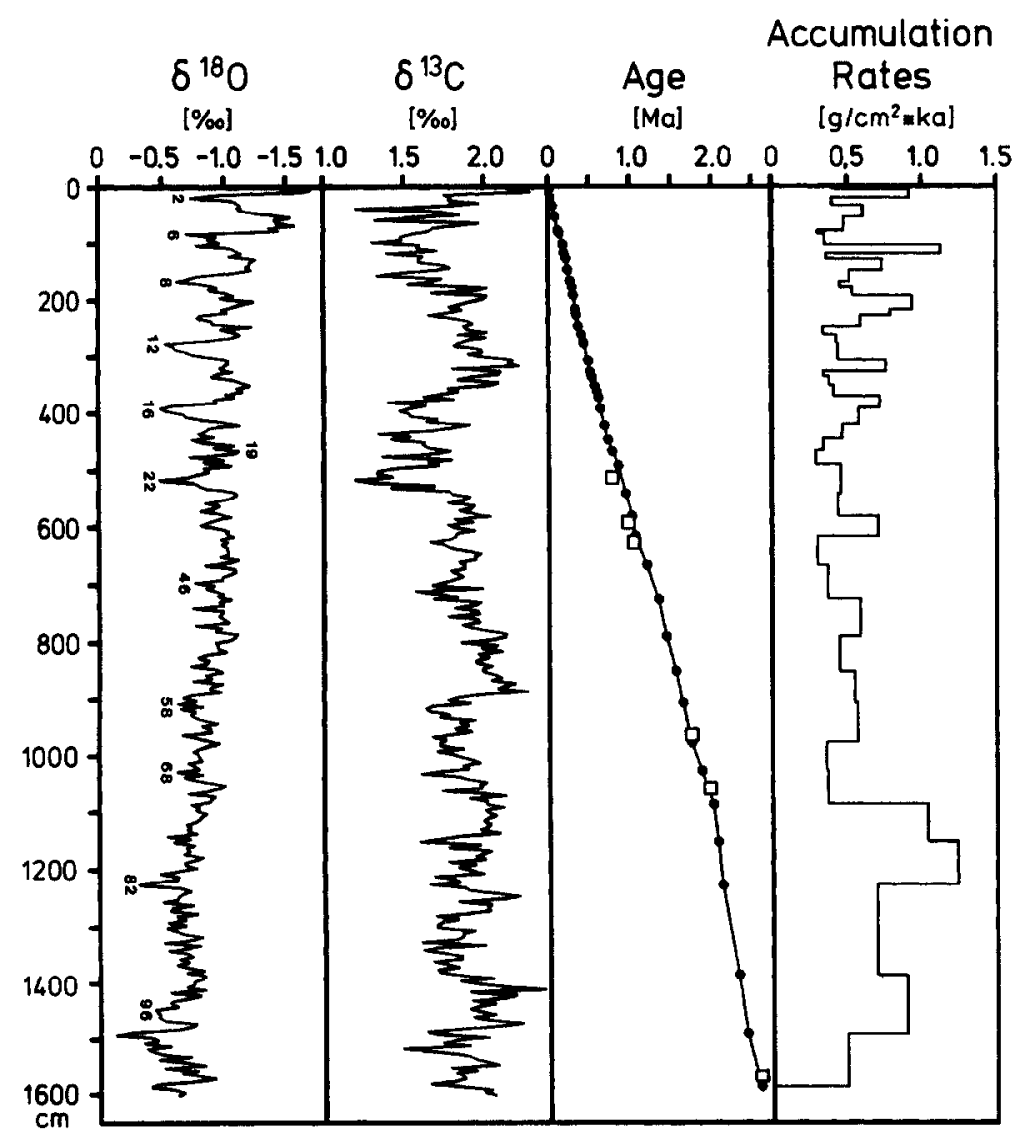

Fig. 8. Oxygen und carbon isotopes, age-depth relation and accumulation rates of core 34KL. Isotope values were measured on Globigerinoides sacculifer. Age control points inferred from the isotope stratigraphy are indicated as dots. For comparison, age control points based on magnetostratigraphy (Table 1) are marked by open squares.

Gauss boundary at $15.70 \mathrm{~m}$ (see Table 1 and Fig. 5).

Because of the low variance in the older part of the $\delta^{18} \mathrm{O}$-record of $34 \mathrm{KL}$, the stratigraphic classification was cross-checked with correlations of the carbon isolope record of Globigerinoides sacculifer of core $34 \mathrm{KL}$ to that of ODP Site 806B for the first $2 \mathrm{Myr}$ (Schmidt et al., 1993). At $5.20 \mathrm{~m}$ core depth, the Mid-Pleistocene Revolution (MPR) is paralleled by a step increase in $\delta^{\mathbf{1 3}} \mathrm{C}$ values of $34 \mathrm{KL}$ to heavier values in the early Pleistocene. Down to the bottom, there are few prominent peaks in this record, i.e. the peak at $9.00 \mathrm{~m}$ depth with an age of $1.6 \mathrm{Ma}$, which may be well correlated to similar features in the Ontong Java Plateau record.

The sedimentation rates in core $34 \mathrm{KL}$ are low throughout the last 2.6 Myr averaging near 6.10 $\mathrm{m} / \mathrm{Myr}$. A slight down-core increase in the depth/age gradient from $5.40 \mathrm{~m} / \mathrm{Myr}$ to 8.30 $\mathrm{m} / \mathrm{Myr}$ occurs at an age of about $2.0 \mathrm{Ma}(10.68 \mathrm{~m})$.

\subsection{Micropaleontology and biostratigraphy}

\subsubsection{Siliceous microfossils and silica diagenesis}

In the highly calcareous sediments of core 34 KL siliceous microfossils (mainly radiolaria and diatoms) are present only in the upper $3 \mathrm{~m}$ of the core (Fig. 9). Even in the near-surface sediments their preservation is only moderate, and their numbers hardly exceed $10^{4}$ to $10^{5}$ per gram sediment. Remains of other siliceous microfossils (Plate I) such as skeletons of silicoflagellates, siliceous sponge spicules, and cysts of Chrysophyceae 
PLATE I

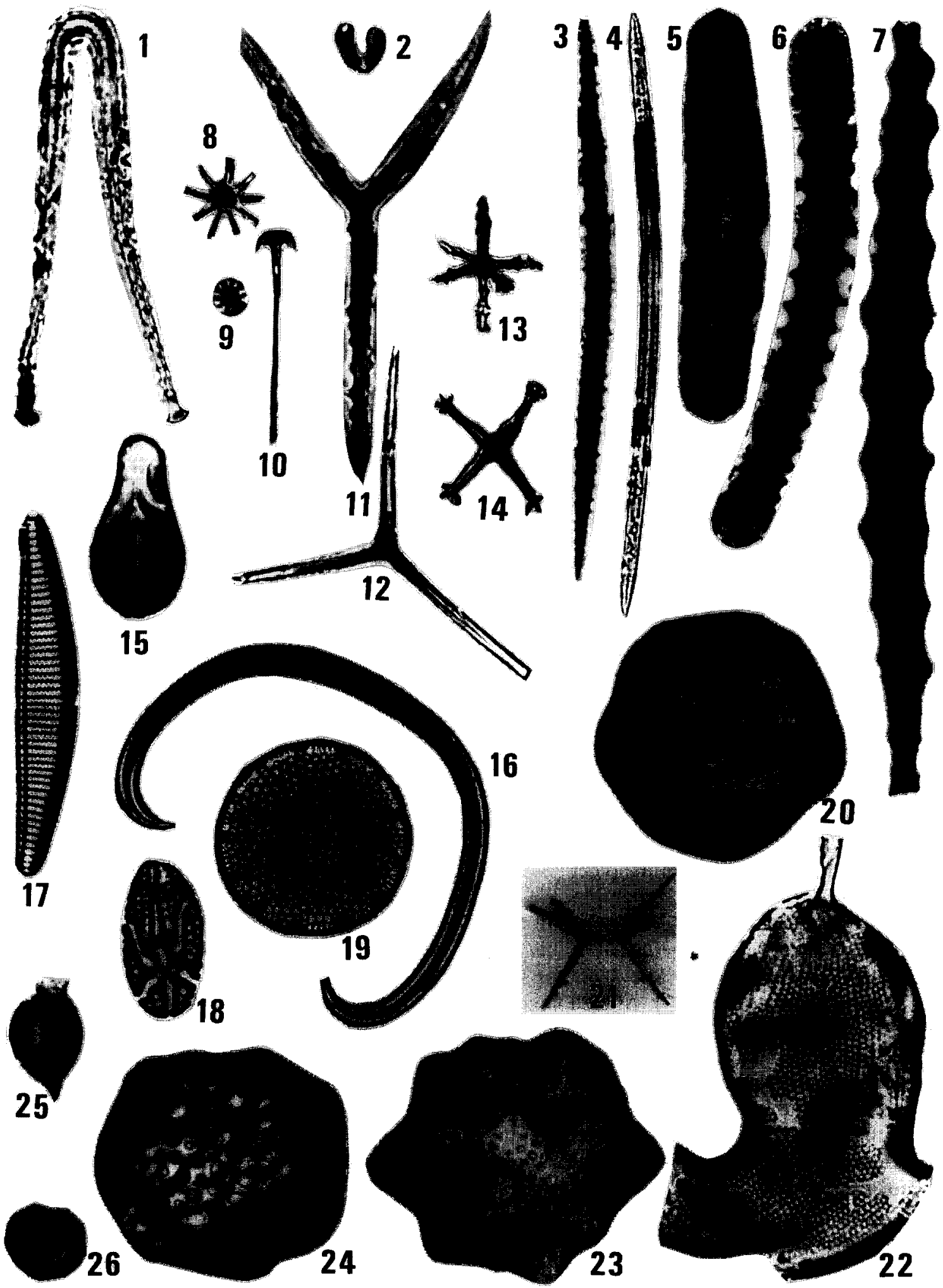


(Archaeomonadaceae) are rarer. Their abundance per gram sediment lies one to two orders of magnitude lower than that of diatoms and radiolaria.

The abundance and preservation of siliceous microfossils decreases down-core. In the two most common groups, the diatoms and radiolaria, the abundance drops in three steps (Fig. 9). The delicate skeletons of phaeodarian radiolaria are present only in the top $10 \mathrm{~cm}$ of the sediment column. At $1.10 \mathrm{~m}$ core depth, the abundance of the main biosiliceous component groups drops by half an order of magnitude. The major drop in abundance before the complete down-core disappearance of all siliceous microfossils lies between 2.10 and 2.20 $\mathrm{m}$ core depth. Here the less dissolution-resistant silicoflagellates (Dictyocha) disappear completely and the other siliceous microfossil groups drop below $10^{3}$ in abundance. Only the more dissolution-resistant Archaeomonodaceae seem to be not affected down to $3.00 \mathrm{~m}$ core depth, below which all siliceous microfossils are dissolved. The abundance curves thus seem to reflect primarily the down-core increasing influence of silica dissolution and its effect on the different microfossil groups according to their dissolution susceptibility.

The abundance of clinoptilolite is inversely correlated with the abundance of siliceous microfossils (Fig. 9). It forms authigenically at low temperatures if the concentration of dissolved silica is sufficient and the concentration of alkali and earth-alkali ions is low (e.g. Coutoure et al., 1978). The characteristic euhedral, platy clinoptilolite in core $34 \mathrm{KL}$ clearly formed during the early diage-

\section{PLATE I}

Siliceous microfossils from Quaternary sediments on the Manihiki Plateau, Core $34 \mathrm{KL}$.

Magnification: (1-19, 22, 25-26) $1500 \times$, (24) $350 \times$, (21, 23) $400 \times$; (20) $407 \times$.

1-13. Sponge spicules examples of types of microscleres $(\mathrm{m})$ and megascleres $(\mathrm{M})$

1. Forceps (m), $34 \mathrm{KL}: 0.72-0.74 \mathrm{~m}$.

2. type not found in the literature $(\mathrm{m}), 34 \mathrm{KL}: 1.12-1.14 \mathrm{~m}$.

3. Acanthomicroxea (M), $34 \mathrm{KL}: 1.12-1.135 \mathrm{~m}$.

4. Oxea (M), $34 \mathrm{KL}: 0.82-0.84 \mathrm{~m}$.

5. Microrhabd (m), $34 \mathrm{KL}: 0.48-0.50 \mathrm{~m}$.

6. Acanthostrongyle (m), $34 \mathrm{KL}: 0.57-0.59 \mathrm{~m}$.

7. Acanthooxea (m), 34 KL: 0.0-0.2 m.

8. Clavule (m), 34 KL: $1.17-1.19 \mathrm{~m}$.

9. Clavule (m), $34 \mathrm{KL}: 0.9-0.11 \mathrm{~m}$.

10. Clavule (m), $34 \mathrm{KL} 1.17-1.185 \mathrm{~m}$.

11. Calthrops (M), $34 \mathrm{KL}: 1.15-1.16 \mathrm{~m}$.

12. Calthrops? (M), $34 \mathrm{KL}: 0.96-0.98 \mathrm{~m}$.

13. Oxyhexaster (m), $34 \mathrm{KL}: 0.77-0.79 \mathrm{~m}$.

14. Oxyhexaster (m), $34 \mathrm{KL}: 1.17-1.185 \mathrm{~m}$.

15. sponge spicule?, type not found in the literature (m), $34 \mathrm{KL}: 0.48-0.50 \mathrm{~m}$.

16. Sigma (m), 34 KL: $1.84-1.86 \mathrm{~m}$.

17-19. Diatom valves.

17. Pseudonotia doliolus, $34 \mathrm{KL}: 0.96-0.98 \mathrm{~m}$.

18. Asteromphalus sacrophagus f, ovatus, $34 \mathrm{KL}: 0.04-0.06 \mathrm{~m}$.

19. Azpeitia tabularis, $34 \mathrm{KL}: 0.96-0.98 \mathrm{~m}$.

20-24. Radiolaria.

20. Collosphaera invaginata, $34 \mathrm{KL}: 0.56-0.58 \mathrm{~m}$.

21. Sphaerozoum punctatum, $34 \mathrm{KL}: 0.71-0.73 \mathrm{~m}$.

22. a phaeodarian radiolarian, $34 \mathrm{KL}: 0.82-0.84 \mathrm{~m}$.

23. Collosphaera sp. A., $34 \mathrm{KL}: 1.18-1.20 \mathrm{~m}$.

20. Collosphaera tuberosa, $34 \mathrm{KL}: 0.09-0.11 \mathrm{~m}$.

25-26. Archaeomonadaceae (cysts of chrysophyceae).

25. rare sculptured type, $34 \mathrm{KL}: 0.42-0.44 \mathrm{~m}$.

26. relatively common unsculptured type, $34 \mathrm{KL}: 0.42-0.44 \mathrm{~m}$. 


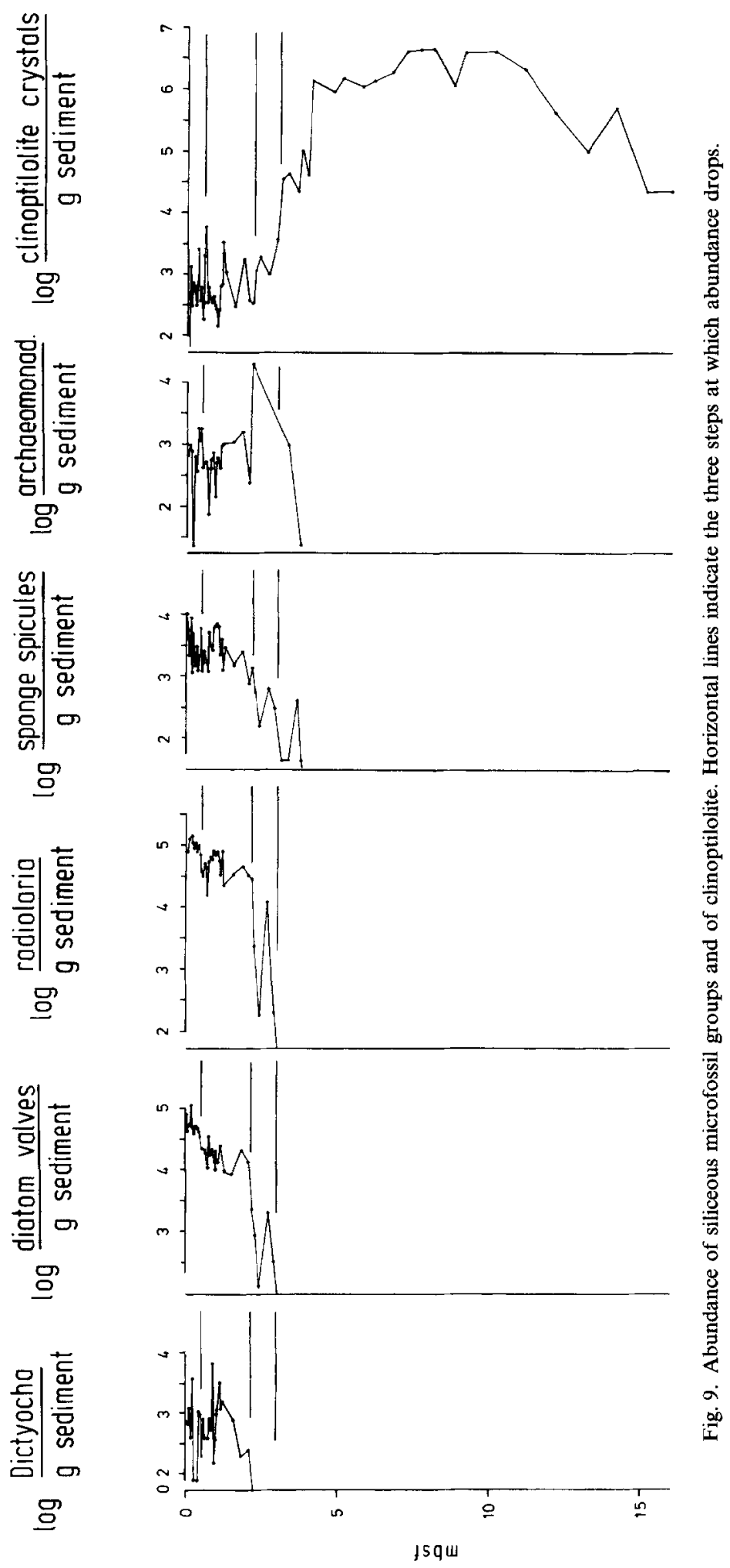


netic alteration of siliceous components. It is present in low amounts in the upper $2.10 \mathrm{~m}$ of sediment, its abundance fluctuating between $10^{2}$ and $10^{4}$ crystals per gram sediment. Only in the uppermost $10 \mathrm{~cm}$ of the sediment column, near the sediment-water interface, where the concentration of dissolved silica in the pore water obviously is low due to dilution effects, clinoptilolite is absent. Below $3.00 \mathrm{~m}$ where siliceous microfossils have been completely dissolved it reaches abundances around $10^{6}$ crystals per gram sediment.

In the upper $2.10 \mathrm{~m}$ the diatom assemblages have characteristic species numbers between 16 and 36 per 100 counted specimens. The dominant species are Azpeitia nodulifer, A. tabularis, Thalassiothrix longissima, Rhizosolenia bergonii, Thalassionema nitzschioides var. parva, and Hemidiscus cuneiformis. These species were already described by Kolbe (1957) as the dominant species in sediments of the equatorial regions of the central Pacific Ocean. Less abundant but also characteristic are Nitzschia marina, Pseudoeunotia doliolus, Rhizosolenia bergonii, Ethmodiscus rex, Roperia tesselata, Pseudotriceratium cinnamomeum, Asteromphalus hiltonianus, A. stellatus, Thalassiosira leptopus, $T$. eccentrica, and Asterolampra marylandica. Most of these species belong to species groups called "tropical and equatorial thanatocoenoses" by Jousé et al. (1971).

As most of the species, which are reported as specific to oligotrophic central oceanic regions, such as Rhizosolenia calcar-avis, R. styliformis, Hemiaulus hauckii, Mastogloia rostrata, Amphora sp., Asterolampra marylandica, and Tropidoneis sp. (compare e.g. Belyaeva, 1970, 1971), were not found or were very rare at this site, these assemblages arc interpretcd to reflect rcasonably fertilc tropical waters. Among the silicoflagellates encountered, only the genus Dictyocha was present, which also argues for relatively fertile surface waters.

None of the diatom species shows abundance fluctuations that parallel the oxygen isotope curve.

Concerning the diatom stratigraphy, the upper $2.50 \mathrm{~m}$ of the core fall within the youngest diatom zone for the Equatorial Pacific, the Pseudoeunotia doliolus Zone of Burckle (1972), as modified by Burckle (1977). The base of this zone cannot be determined in core $34 \mathrm{KL}$ due to heavy silica dissolution below $2.20 \mathrm{~m}$ and the absolute absence of diatoms below $3.00 \mathrm{~m}$ core depth.

The sponge spicules recorded (see Plate I) consist predominantly of microscleres. Following the terminology of Wiedenmayer (1977), most types are microscleres, as Oxyspheraster, Oxyhexaster, Spiraster, Clavule, Sigma, Forceps, Isochela, Microxa, Acanthooxea, Acanthostrongyle, Microtylostyle and others. Megascleres are rare. Among the monaxons Oxea, Strongyloxea, Styloid, Tylostyle, and Calthrops were encountered. Such a siliceous sponge spicule assemblage is typical of 2000-3000 m water depth (J. Reitner, pers. commun., 1993), and thus can be interpreted as autochthonous.

The radiolarian faunas represent a mainly tropical-subtropical assemblage. As with the diatoms, the abundance changes of radiolaria species do not show apparent correlation with the oxygen isotope curve.

Throughout the upper $2.70 \mathrm{~m}$ of the core, more than 150 radiolarian species were identified. Many of the species found have a long stratigraphic range, occurring from the late Pliocene to present, e.g. Collosphaera huxleyi, Panartus tetrathalamus, Amphirhopalum ypsilon, Spongaster tetras tetras, Pterocanium p. praetextum, Theocorythium $t$. trachelium, Polysolenia spinosa, Lithomitra arachnea and Bothryostrobus auritum. Typical Pliocene to early Pleistocene species, however, were not found. Sphaerozoum punctatum and Collosphaera lappacea, characteristic species of the late Pleistocene, are present throughout the upper $2.25 \mathrm{~m}$.

Within the upper $2.10 \mathrm{~m}$ of the core, two radiolarian zones can be recognized. The uppermost radiolarian zone, the Buccinosphaera invaginata Zone, can be identified in the uppermost 1.20-1.24 $\mathrm{m}$ of the core. The base of this zone is defined by the first occurrence (FO) of B. invaginata, an easily recognizable species. This datum is thought to be near-synchronous globally, having an age of $0.17-0.21 \mathrm{Ma}$, thus occurring near the isotope stage $6 / 7$ transition (see Fig. 8 ), in the upper part of the Brunhes Epoch (e.g. Knoll and Johnson, 1975; Bjørklund and Goll, 1979; Johnson et al., 1989).

The interval from $1.20-1.24 \mathrm{~cm}$ to $1.85 \mathrm{~m}$ is 
referred to the Collosphaera tuberosa Zone. As the preservation of biogenic opal becomes poor downcore, the first evolutionary occurrence of this species, which should occur at $0.58 \mathrm{Ma}$ in the transitional interval between oxygen isotopic stages 16 and 15 (Nigrini, 1971; Johnson et al., 1989), is not documented in this core.

The fact that the radiolarian species Stylatractus universus was not found in the upper $3 \mathrm{~m}$ of the sediment column corroborates the interpretation that the first occurrence (FO) of Collosphaera tuberosa indeed is too high in the core due to dissolution effects. According to Hays (1970), Hays et al. (1969), Hays and Shackleton (1976), Morley and Shackleton (1978) and Johnson et al. (1989), S. universus has its last occurrence around $0.42 \mathrm{Ma}$ near the end of isotopic stage 11 -thus, it should range above the FO of $C$. tuberosa and should be present up to $2.50 \mathrm{~m}$ core depth. The base of the $C$. tuberosa Zone, therefore, must lie below $1.90 \mathrm{~m}$.

\subsubsection{Calcareous nannofossils}

The biostratigraphic assignment of the calcareous nannoplankton samples was based on the zonation of Martini and Müller (1986). According to IIills and Thierstein (1989), who tested this zonation scheme on 30 drill holes of the Deep Sea Drilling Project, seven of nine coccolith biostratigraphic datums in the late Pliocene and Pleistocene are reliable. These datums were used to define the last five zones of the late Pliocene and Pleistocene in core $34 \mathrm{KL}$ (Fig. 10). Their index species are shown on Plate II.

The correlation of biostratigraphic boundaries based on calcareous nannoplankton with the magnetostratigraphy (Fig. 10) gives only one point of comparison at the Pliocene/Pleistocene boundary.

\subsubsection{Benthic foraminifers}

Sixty-one different benthic foraminiferal species were found. Cibicidoides wuellerstorfi and Oridorsalis umbonatus are the dominant faunal elements with average percentages of 30 and $12 \%$, respectively. Melonis pompilioides, Pullenia bulloides, Anomalina globulosa and Pyrgo murrhina are frequent species. Common and occasionally dominant faunal elements are Cibicidoides robertsonianus, Eggerella bradyi, Gyroidina zeelandica, Karreriella bradyi, Melonis barleeanum, Nonion sp. and Pyrgo serrata. This benthic foraminiferal assemblage displays bathyal characteristics. It shows close affinities to the "plate bathyal assemblage" of Resig (1981). Epistominella umbonifera and other typical bathyal species from the Pacific are rare. Their scarcity may, however, result from the chosen grain-size fraction. Tests of Epistominella spp. usually have a smaller diameter and most of them are recorded in the $63-250 \mu \mathrm{m}$ grain-size fraction. The absence or scarcity of productivity-sensitive species of Bolivina, Bulimina, Chilostomella and Uvigerina indicates that the flux of particulate organic matter to the sea floor at the Manihiki Plateau is lower than at the same water depth on the western continental margin of South America or the Ontong-Java Plateau (Burke et al., 1993; Ingle et al., 1980).

The most common species are numerically abundant throughout the core and their percentages show irregular fluctuations which are linked in part with variations in oxygen and carbon isotopic records. Only a few species display a consistent pattern of higher abundances over core intervals or distinct stratigraphic ranges (Fig. 11). Dentalina specimens are much more frequent below $9.59 \mathrm{~m}$, while Nonion sp. occur with significantly higher percentages above $9.91 \mathrm{~m}$. Few specimens of Cibicidoides pseudoungerianus were found in most of the samples between $9.08 \mathrm{~m}$ and $4.30 \mathrm{~m}$. This species is rare farther below and was not recorded above that interval. The last occurrences (LO) of Pleurostomella brevis and Pleurostomella alternans were found at $6.81 \mathrm{~m}$ and $6.42 \mathrm{~m}$, respectively. Nodogenerina sagriensis disappears later, at 5.72 $\mathrm{m}$. The only first occurrence (FO) datum, which is recorded higher in the upper part of the section, is that of Fissurina seminiformis at $4.51 \mathrm{~m}$.

The outlined events are concentrated at certain intervals (Figs. 11 and 15). The uppermost interval from $4.30 \mathrm{~m}$ to $4.51 \mathrm{~m}$ is confined by the $\mathrm{LO}$ of Cibicidoides pseudoungerianus and the FO of Fissurina seminiformis. This interval comprises most of oxygen isotope stage $18(0.70-0.74 \mathrm{Ma})$. The second interval of change ranges from $5.72 \mathrm{~m}$ to $6.81 \mathrm{~m}$ and comprises the LO datums of 


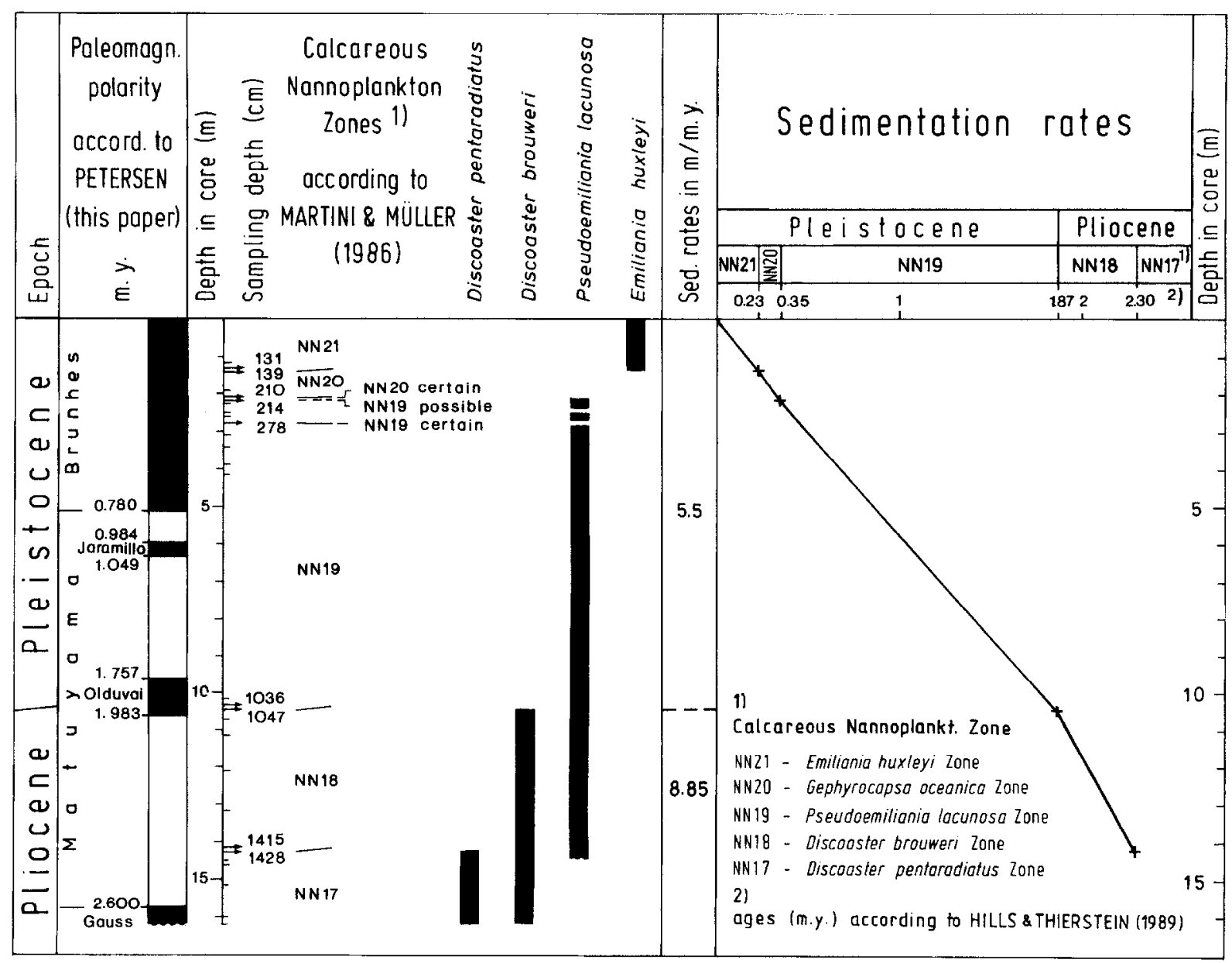

Fig. 10. Distribution of calcareous nannoplankton index species and sedimentation rates in core $34 \mathrm{KL}$ calibrated to magnetostratigraphy.

Pleurostomella and Nodogenerina species. The second interval includes oxygen isotope stages 29 through 36 and may be dated as 1.01-1.24 Ma. The third interval occurs between $9.08 \mathrm{~m}$ and 9.91 $\mathrm{m}$, i.e. between oxygen isotope stages 58 through $63(1.65-1.79 \mathrm{Ma})$ where the frequencies and abundances of Dentalina and Nonion specimens and Cibicidoides pseudoungerianus change (Fig. 15).

\subsubsection{Planktonic foraminifers}

Planktonic foraminifers are present throughout core $34 \mathrm{KL}$. Together with calcareous nannofossils, they represent the dominant calcareous microfossil group. The preservation of the planktonic foraminifers is excellent and no traces of dissolution were observed.

Species of planktonic foraminifers identified are as follows (frequencies are related to the $>200 \mu \mathrm{m}$ grain-size fraction):

(1) abundant to common are Globigerinoides ruber (54\%), Gs. sacculifer trilobus $(9 \%)$, and Globigerinita glutinata $(8 \%)$;

(2) common to rare are Globigerinoides ct. trilobus $(5 \%)$ (which has a more compact test than Gs. trilobus), Gs. conglobatus (5\%), Globigerinella aequilateralis (4\%), Gs. fistulosus (4\%), Sphaeroidinella dehiscens (3\%), Candeina nitida 

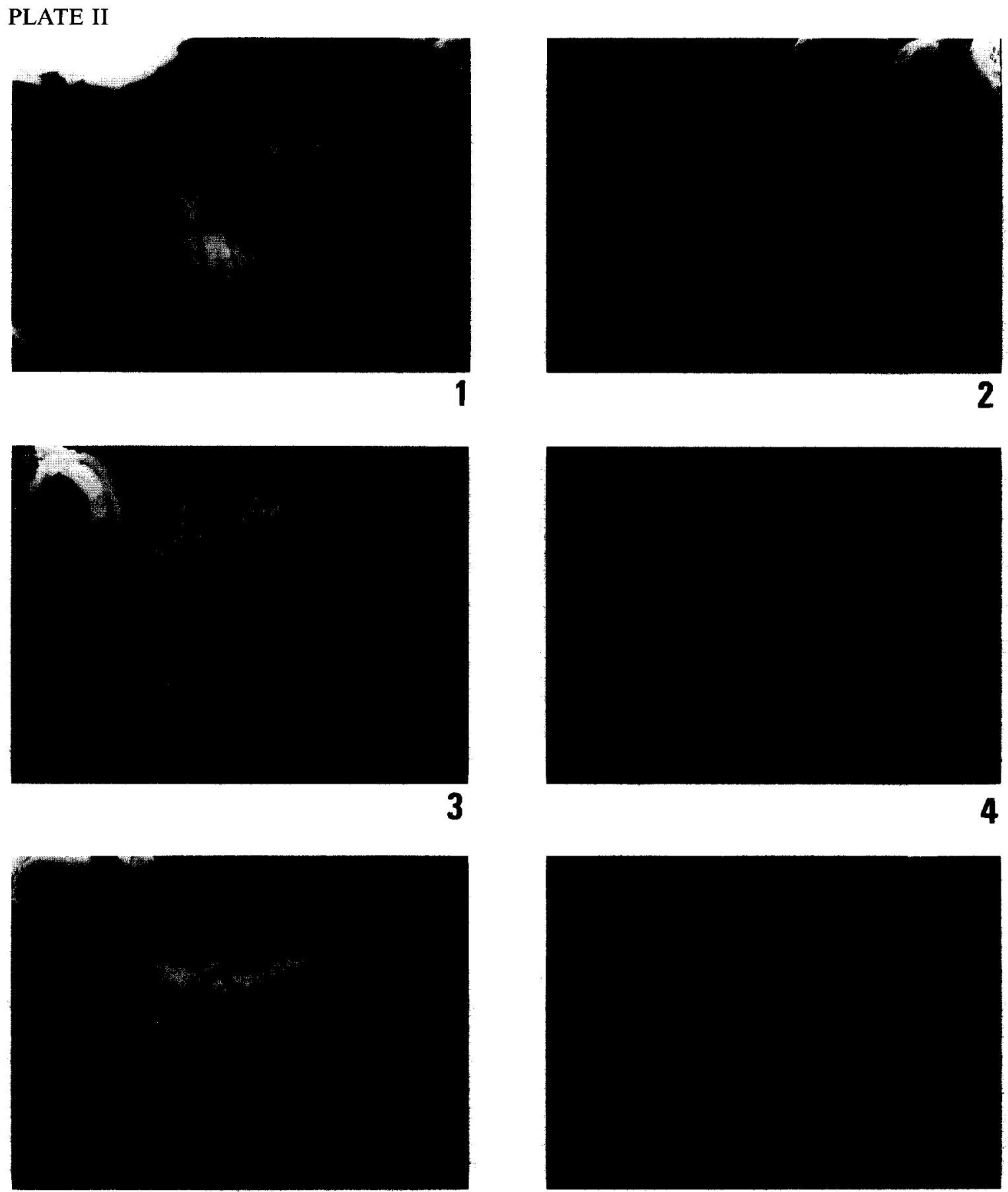
$(2 \%)$, Orbulina universa $(2 \%)$, and Globorotalia tumida $(2 \%)$

(3) rare species (less than 2\%) are Hastigerina pelagica, $H$. parapelagica, Globigerinella obesa-calida, Ge calida s.s., Beella preaedigitata, B. digitata, Globigerinoides parkerae, Globigerina rubescens, $G$. cf. bulloides (which has often 4.5-5 slowly growing chambers in the final whorl), Orbulina bilobata, Globigerinoides gomitulus/pink, (see below), Gs. cf. fistulosus ("hystricosus"), Sphaeroidinella excavata, Gs. ruber/pink, Gs. elongatus-pyramidalis, Neogloboquadrina cf. dutertrei, Nq. humerosa, Pulleniatina obliquiloculata, Globoquadrina pseudofoliata, Globorotaloides hexagonus, Globorotalia crassaformis, Gr. oceanica, Gr. tosaensis, Gr. truncatulinoides, Gr. scitula, Gr. theyeri, Gr. menardii, Gr. menardii neoflexuosa, Gr. ungulata, Gr. tumida flexuosa, Bolliella adamsi, and Streptochilus tokelauae.

Species composition of planktonic foraminifers of core $34 \mathrm{KL}$ is uniform during the late Pliocene and Pleistocene. It is typical of sediments of equatorial, tropical to subtropical regions of the central Pacific Ocean (Parker, 1962, 1967).

The distribution of planktonic foraminiferal index species in the core $34 \mathrm{KL}$ from the Manihiki Plateau is given in Fig. 12.

Two zones of the planktonic foraminiferal biostratigraphic schemes were recognized:

(1) the Globorotalia truncatulinoides Zone ( $\mathrm{N}$ 22) between the top of the core and 9.37-9.40 m which is according to our calcareous nannoplankton data (parts of NN 19, exclusive the basal part, NN 20, NN 21) of early to late Pleistocene age, and

(2) the Globorotalia tosaensis Zone ( $\mathbf{N} 21$ ) between $9.37-9.40 \mathrm{~m}$ and the base of the core which is according to our calcareous nannoplankton data (basal part of NN 19, NN 18, and parts of NN 17) of earliest Pleistocene to late Pliocene age.

The Globigerinella calida Zone and its subzones (see Chapronière, 1991) were not separated from the Globorotalia truncatulinoides Zone due to the difficulty in separating Globigerinella praecalida and Globigerinella calida within the interval of the late NN 19 to the basal NN 21 zones. Within the NN 21 Zone, two of the subzones as recognized by Chapronière (1991) - the Pulleniatina finalis and the Bolliella adamsi subzones-are present (compare Fig. 12).

The first occurrence of Globorotalia truncatulinoides does not coincide with the Pliocene/ Pleistocene boundary as defined by the last occurrence of Discoaster brouweri at 10.36-10.47 m. It also does not coincide with the top or the base of the Olduvai Event which was recognized between 9.60-9.70 $\mathrm{m}$ and $10.50-10.70 \mathrm{~m}$, respectively. It should be mentioned already here that according to Dowsett (1989) and Hills and Thierstein (1989) the first occurrence of Globorotalia truncatulinoides is highly diachronous within the southern Pacific, especially over different climatic regions (further discussion below).

According to Chapronière (1991) and Chapronière and Nishi (1994), there are more than 20 potential planktonic foraminiferal events within the late Pliocene and the Pleistocene for the Pacific region. Those identified in core $34 \mathrm{KL}$ are in descending order ( $\mathrm{LO}=$ last occurrence, $\mathrm{FO}=$ first occurrence):

(1) FO B. adamsi, $0.27-0.30 \mathrm{~m}$

(2) LO Gs. ruber/pink, $0.87-0.90 \mathrm{~m}$

(3) LO Gr. tumida flexuosa, $1.14-1.16 \mathrm{~m}$

(4) LO Gq. pseudofoliata, $1.29-1.32 \mathrm{~m}$

(5) FO Gs. ruber/pink, $2.58-2.61 \mathrm{~m}$

(6) LO Gr. tosaensis, $3.38-3.41 \mathrm{~m}$

PLATE II

Calcareous nannoplankton index species of core $34 \mathrm{KL}$.

1. Emiliania huxleyi (Lohmann).

2. Gephyrocapsa oceanica (Kamptner).

3, 4. Pseudoemiliania lacunosa (Kamptner).

5. Discoaster brouweri (Tan).

6. Discoaster pentaradiatus (Tan) 


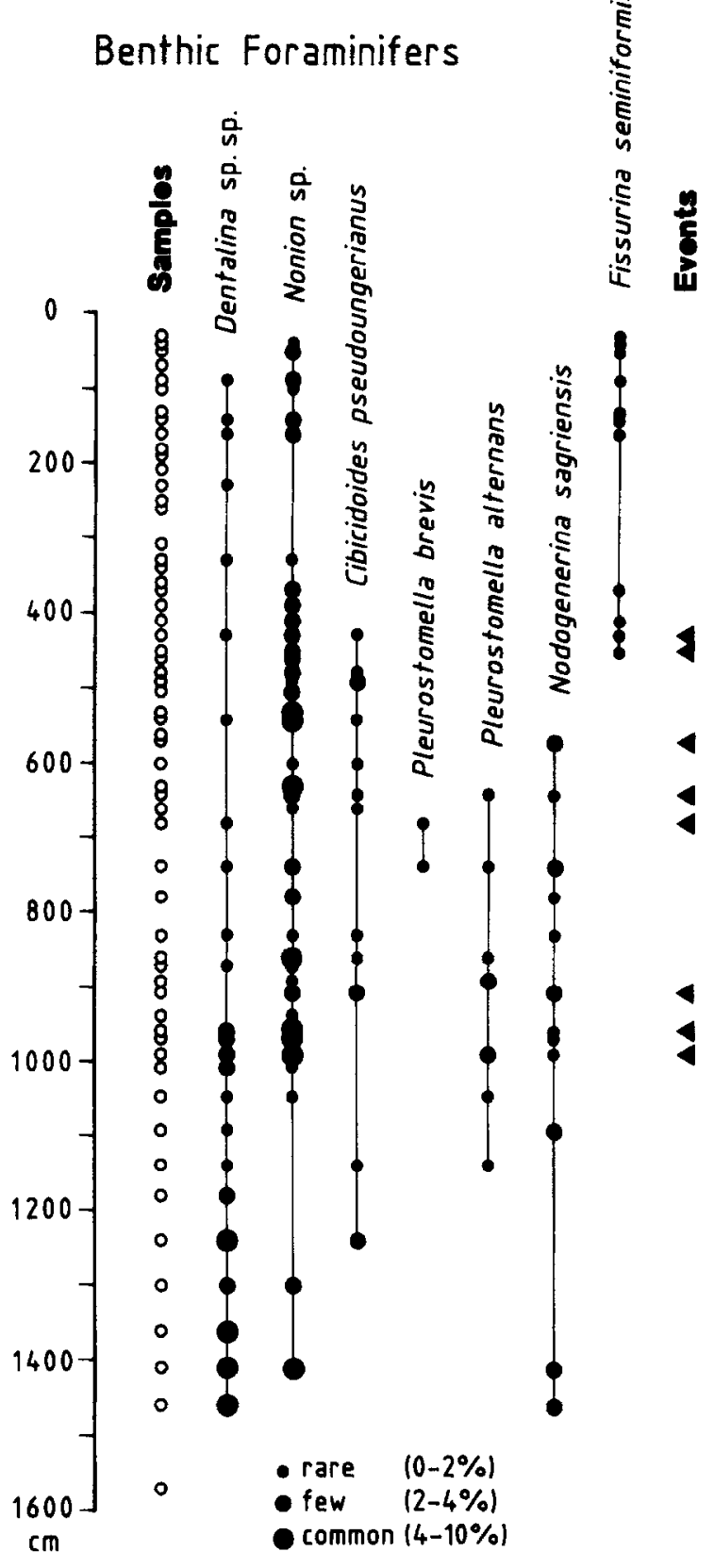

Fig. 11. Abundances, stratigraphic ranges and bioevents of benthic foraminifers from core $34 \mathrm{KL}$.

(7) LO Gs. gomitulus/pink, $4.59-4.62 \mathrm{~m}$

(8) FO Gs. gomitulus/pink, 7.78-7.81 m

(9) LO Gs. fistulosus, 9.14-9.16 m

(10) FO B. digitata, $9.14-9.16 \mathrm{~m}$

(11) FO Gt. truncatulinoides, $9.37-9.40 \mathrm{~m}$
The index species $G$. ruber/pink and $G$. gomitulus/pink are shown on Plate III.

Fig. 13 shows the abundance fluctuations of the frequent planktonic foraminiferal species versus depth in core. It is correlated with oxygen isotope periods, paleomagnetic events and chrons and calcareous nannofossil and planktonic foraminiferal zonations.

\section{Discussion}

The generally accepted concept of Pacific plate motion assumes that the Pacific plate moves $10 \mathrm{~cm}$ per year to the west northwest. This state of motion has persisted for at least the last $10 \mathrm{Ma}$. According to this model, the site of core $34 \mathrm{KL}$ was about one degree south and two degrees east of its present position, when the oldest sediments of the core were deposited at $2.6 \mathrm{Ma}$, i.e., it has hardly changed. Since the basement of the Manihiki Plateau was formed probably in Aptian times or earlier (Lanphere and Dalrymple, 1976), the subsidence of the site $34 \mathrm{KL}$, which can be assumed as less than a few tens of meters, can be neglected for the last $2.6 \mathrm{Ma}$.

The small lateral and vertical motions at the site have had hardly any effect on the depositional regimes. The site moved closer to the equator, but apparently remained within the realm of the western extension of the South Equatorial Current, i.e., away from the equatorial upwelling with its high primary productivity. The site also remained well above the equatorial calcite compensation depth (CCD), which was deeper than $4500 \mathrm{~m}$ during the Pliocene and Pleistocene (Van Andel et al., 1975; Archer, 1991).

The smooth High Plateau surface of the Manihiki Plateau shows no evidence of current activity at present. The lack of angular unconformities in the $3.5 \mathrm{kHz}$ records for much of the High Plateau indicates that erosion and redepositon are rare. Bottom photographs show a "tranquil tracked and burrowed surface" (Heezen and Hollister, 1971, p. 528). This matches the conspicuous lack of reworked and redeposited microfossils. 


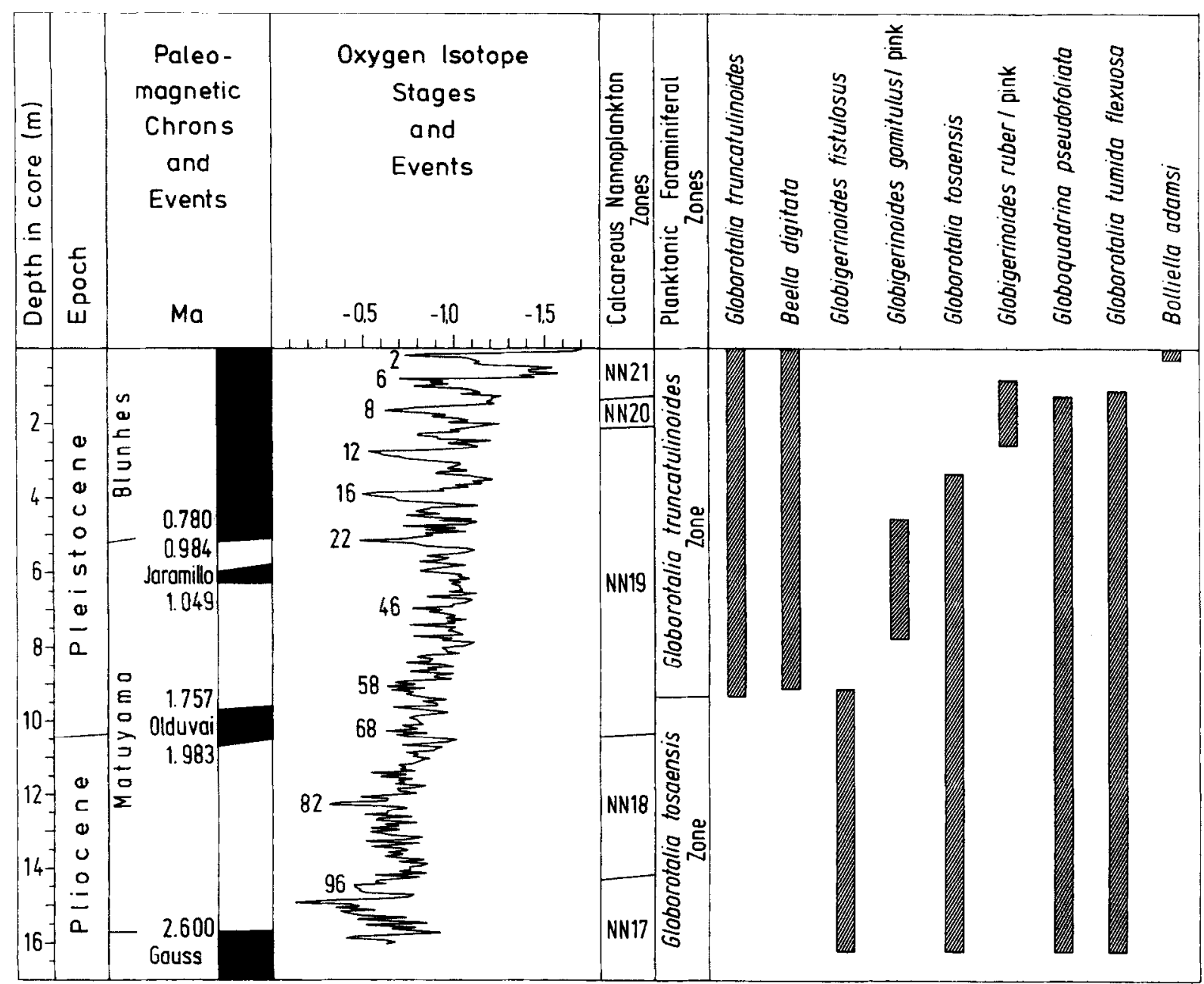

Fig. 12. Distribution of planktonic foraminiferal index species in core 34KL calibrated to the magnetostratigraphy, the oxygen isotope stages and events and the calcareous nannoplankton biostratigraphy.

\subsection{Productivity, carbonate and silica deposition}

Water depths at Site 34KL have been above the calcareous nannoplankton and foraminiferal lysocline since $2.6 \mathrm{Ma}$, a fact that is responsible for the good preservation of calcareous microfossils. Values of 93-97\% (calcareous nannofossils and foraminiferal tests) indicate a low primary productivity dominated by nannoplankton and foraminifers. The flux of other pelagic particles, such as the remains of siliceous micro-organisms and detrital minerals, was minor.

From the low magnetization intensity and, in turn, from the low number of magnetosomes, we conclude that the metabolic activity in the sediments was only moderate. This may be indicative of a relatively low input of nutrients and organic matter, which in turn matches the low surface water productivity of $40 \mathrm{gC} / \mathrm{m}^{2} /$ year at the site location (Berger et al., 1987). Also the bulk accumulation rates at the $34 \mathrm{KL}$ location were persistently low. In the middle and late Pleistocene, values vary around $0.5 \mathrm{~g} / \mathrm{cm}^{2} / \mathrm{kyr}$, and around 0.8 $\mathrm{g} / \mathrm{cm}^{2} / \mathrm{kyr}$ in the section below (Fig. 8). These values are significantly lower than equatorial bulk accumulation rates (Van Andel et al., 1975) which 


\section{PLATE III}

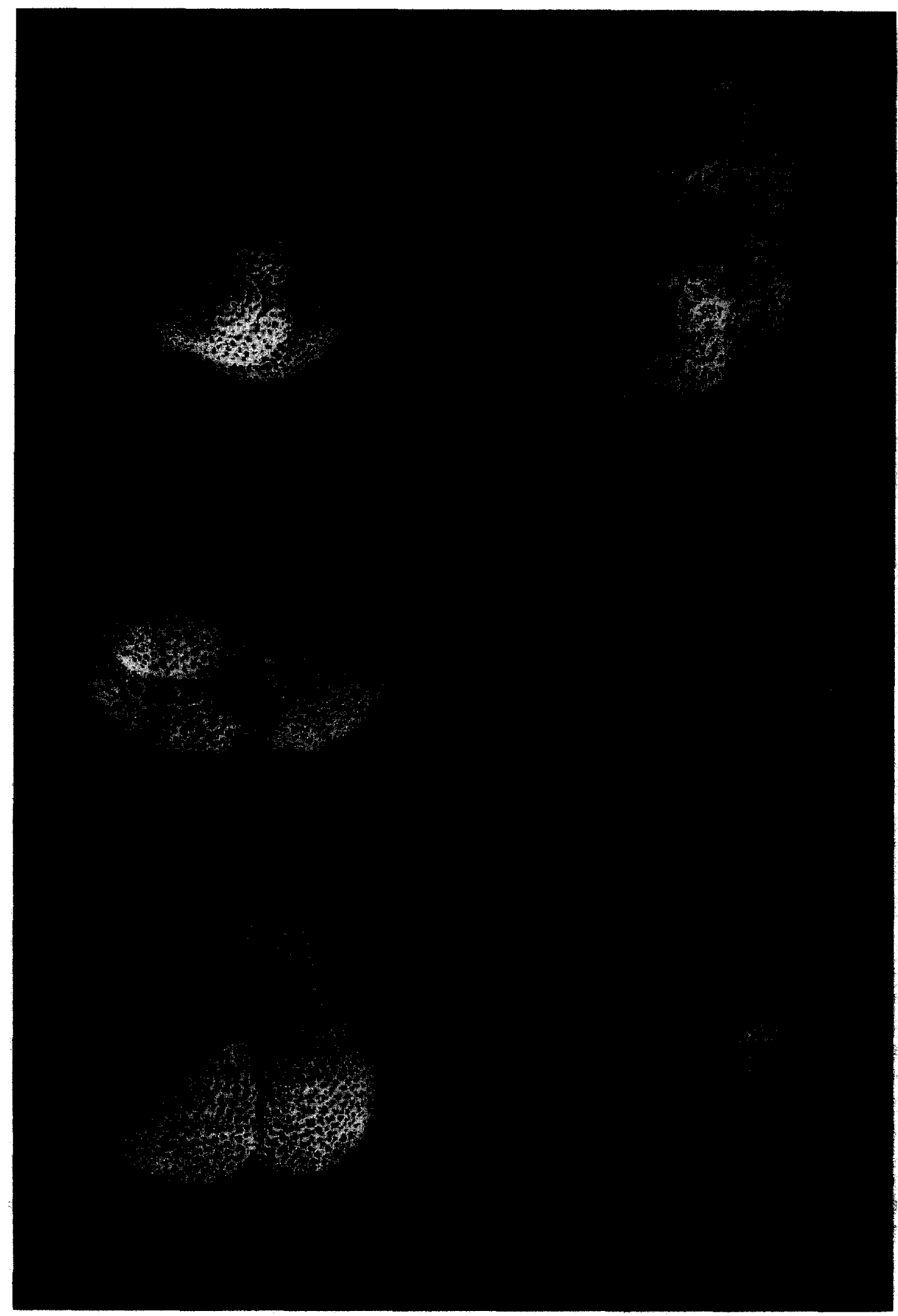


continued to exceed $1 \mathrm{~g} / \mathrm{cm}^{2} / \mathrm{kyr}$ over the last $6 \mathrm{Myr}$.

Low productivity results in low concentrations of biogenic opal. However, the occurrence of clinoptilolite indicates that a certain flux of biogenic silica persisted during the Pleistocene and late Pliocene (see Figs. 4 and 9), because earlydiagenetic dissolution of opal $\mathrm{A}$ is considered as the primary source of clinoptilolite (e.g. Kastner and Stonecipher, 1978).

The down-core increase in sedimentation rates from $5.4 \mathrm{~m} / \mathrm{Myr}$ to $8.7 \mathrm{~m} / \mathrm{Myr}$ lies very close to the LO of Discoaster brouweri, which defines the Pliocene/Pleistocene boundary biostratigraphically. This increase can also be observed at all sites of ODP Leg 130, Ontong-Java Plateau (Berger et al., 1993a,b). Compared to ODP Site 806, located at about the same water depth of $2520 \mathrm{~m}$ at the Ontong-Java Plateau with a sedimentation rate of $22 \mathrm{~m} / \mathrm{Myr}$, the sedimentation rate in core 34KL $(6.10 \mathrm{~m} / \mathrm{Myr})$ is less than one third. This difference may originate from a lower primary productivity in the euphotic zone at greater distance from the equator. Therefore, core $34 \mathrm{KL}$ forms an excellent example for a pelagic sediment record of a low-productivity region. In harmony with this conclusion, all microfossil assemblages clearly record the infertile "blue ocean" of the subtropics.

\subsection{Magneto- and isotope-stratigraphic record}

A lack of calcite dissolution largely prevented the sediment compaction by collapsing grainsupported pore space. Therefore, elongated or platy particles were hardly aligned parallel to the bedding, which in turn also left the magnetosomes in place without rotation. This may be the reason for the highly accurate magnetostratigraphic record being achieved from core $34 \mathrm{KL}$ despite the low NRM intensities measured at all core depths. As a result, the Gauss-Matuyama boundary, the
Matuyama-Brunhes boundary as well as the Olduvai event were clearly identified. For the Jaramillo event only the upper boundary can be identified with certainty. Fig. 14 summarizes the magnetostratigraphic and the biostratigraphic datum levels and zonations of core 34KL. Fig. 15 summarizes the major magnetostratigraphic, oxygen-isotope stratigraphic, lithostratigraphic, and biostratigraphic units and events.

The $\delta^{18} \mathrm{O}$ record of core $34 \mathrm{KL}$ generally agrees with the isotope stratigraphic record found at the Ontong-Java Plateau, about $4000 \mathrm{~km}$ to the west (Berger and Wefer, 1992; Berger et al., 1993a; Bickert et al., 1993). The orbitally tuned cyclicity is recognized in both records, although the low resolution of the $34 \mathrm{KL}$ record (about $8 \mathrm{kyr}$ per 5 -cm sample interval) does not permit spectral analyses. Berger and Wefer (1992) defined the obliquity-cycle dominated Laplace Period between 1.84 and $1.2 \mathrm{Ma}$, although-as seen from Shackleton et al. (1989) - this period might extend down to at least 2.5 Myr. They also defined the 100 kyr-cycle dominated Milankovitch Period between $0.62 \mathrm{Ma}$ and today. The record from the Ontong-Java Plateau also shows a transitional interval (Croll Period) between 1.23 and $0.62 \mathrm{Ma}$ characterized by a decreasing power in the $100 \mathrm{kyr}$ period of the oxygen isotope curve. In the $34 \mathrm{KL}$ record, this transition is not well established. In contrast, a clear step in amplitude occurs at 5.20 $\mathrm{m}$ depth, at oxygen isotope stage $22 / 23$ boundary (about $0.9 \mathrm{Ma}$ ) representing the Mid-Pleistocene Revolution (MPR) in this core.

If the isotope events are compared with the magnetostratigraphic datums, there is a fairly good agreement for all paleomagnetic ages (according to the new age scale of Cande and Kent, 1992). The error in depth is less than $\pm 0.15 \mathrm{~m}$, except for the determination of the Brunhes-Matuyama boundary. This magnetic reversal is positioned between $5.10 \mathrm{~m}$ and $5.20 \mathrm{~m}$ depth in core, whereas the isotopic stage 19.1 is defined at $4.68 \mathrm{~m}$. We

PLATE III

Planktonic foraminiferal index species of core $34 \mathrm{KL}$.

1-3. Globigerinoides ruber (D'Orbigny), pink-coloured variety. $34 \mathrm{KL}: 2.14-2.16 \mathrm{~m}$.

4-6. Globigerinoides gomitulus (Seguenza), pink-coloured variety. $34 \mathrm{KL}$ : 5.14-5.16 m. Scale: $100 \mu \mathrm{m}$. 


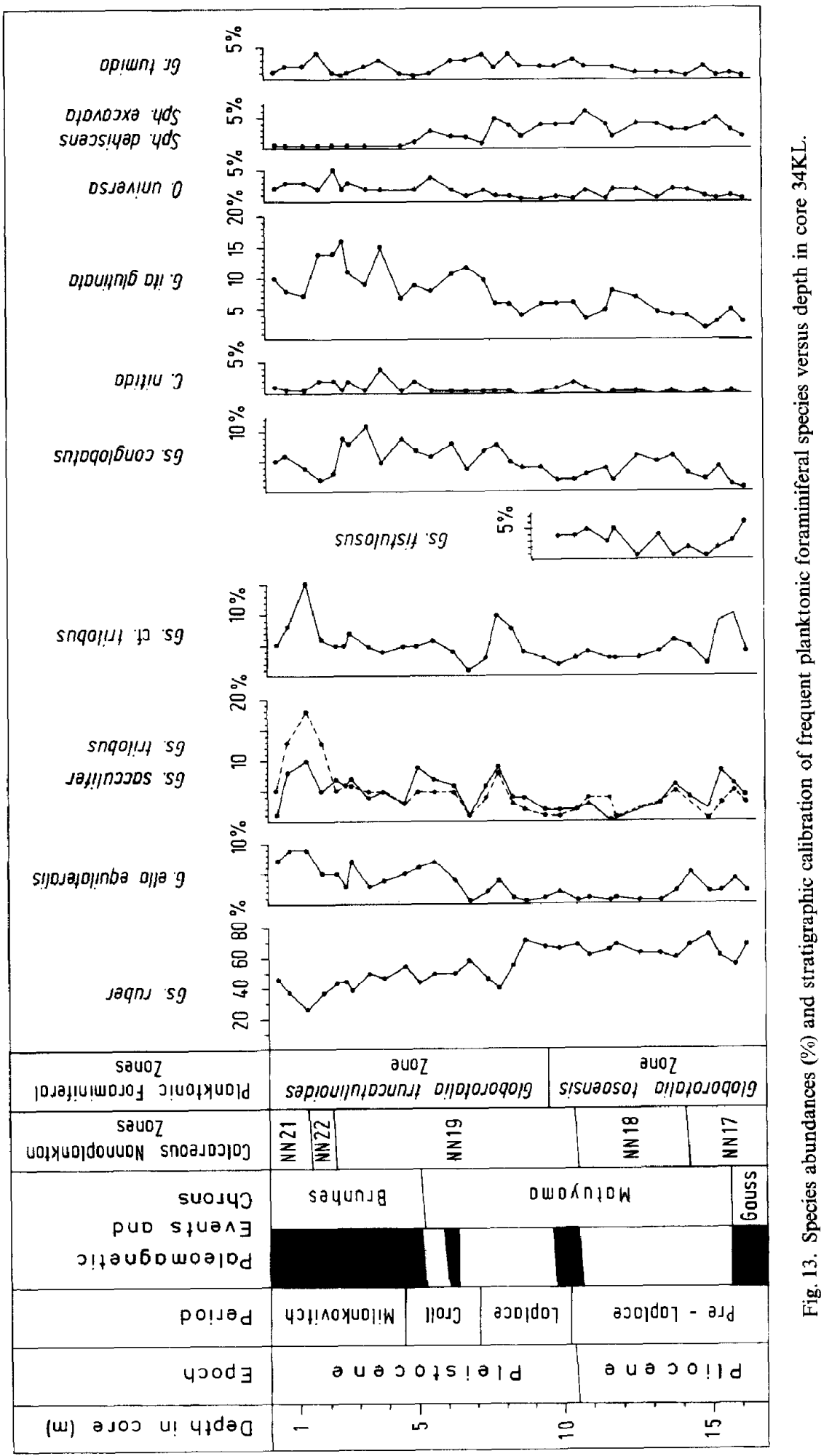




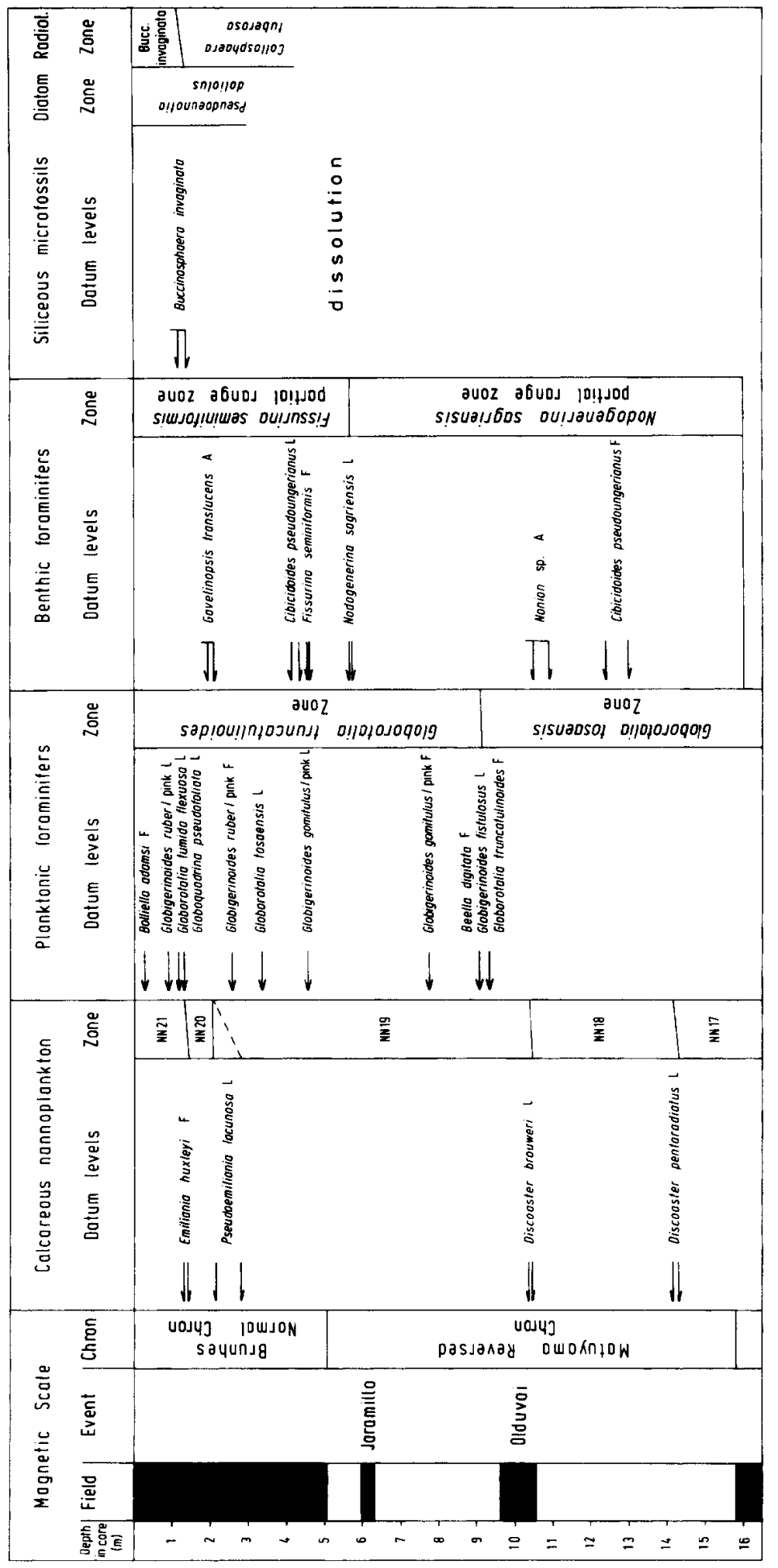

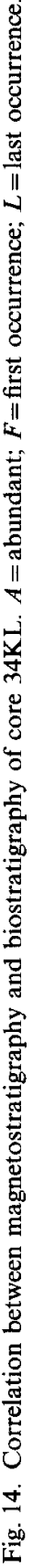




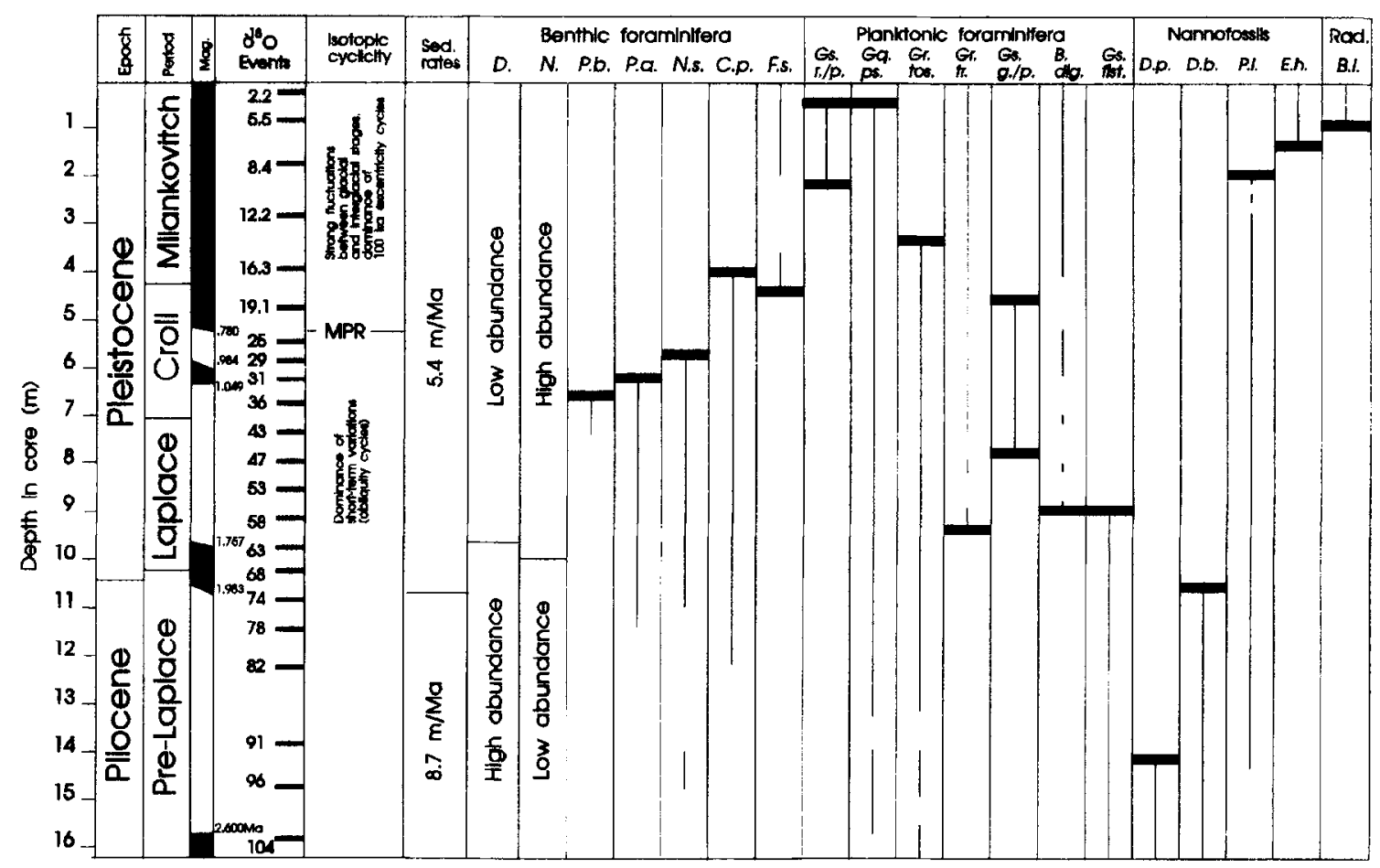

Fig. 15. Synopsis of major magnetostratigraphic, oxygen isotope stratigraphic, lithostratigraphic, and biostratigraphic epochs and events. $M P R=$ Mid-Pleistocene Revolution. Abbreviations of the species names: $D .=$ Dentalina, $N .=$ Nonion, P.b. $=$ Pleurostomella brevis, P.a. = Plewrostomella alternans, $N . s .=$ Nodogenerina sagriensis, C.p. =Cibicidoides pseudoungerianus, F.s. $=F i s s u r i n a$ seminiformis, Gs.r./p.=Globigerinoides ruber/pink, Gq.ps.=Globoquadrina pseudofoliata, Gr.tos.=Globorotalia tosaensis, Gs.g./p. = Globigerinoides gomitulus/pink, B.dig. =Beella digitata, Gs.fist.$=$ Globigerinoides fistulosus, D.p. $=$ Discoaster pentaradiatus, D.b. $=$ Discoaster brouweri, P.l.=Pseudoemiliania lacunosa, E.h.=Emiliania huxleyi, B.i.=Buccinosphaera invaginata. Numbers at paleomagnetic boundaries are ages according to the time scale of Cande and Kent (1992). Normally magnetized core sections are presented as black intervals.

have no explanation for this discrepancy in depth. There is no evidence for a hiatus in this core interval.

\subsection{Calibration of biostratigraphic datums}

A few bioevents and small scale siliceous microfossil fluctuations correlate well with the oxygen isotopic and paleomagnetic events. The lower boundary of the radiolarian Buccinosphaera invaginata Zone correlates with the oxygen isotopic stage 6/7 transition and thus supports a globally synchronous age of $0.17-0.21 \mathrm{Ma}$ for this biostratigraphic datum.

Four calcareous nannoplankton zonal boundaries in core $34 \mathrm{KL}$ correlate moderately well with oxygen isotopic events: NN 20/21 with oxygen isotope event 8 , NN 19/20 with oxygen isotope event 12.2 (possibly 10 !), NN $18 / 19$ with oxygen isotope event 70 , and $\mathrm{NN} 17 / 18$ with oxygen isotope event 93 . The NN 18/19 boundary (extinction of Discoaster brouweri) marks the beginning of the Pleistocene biostratigraphically and falls within the lower part of the paleomagnetic Olduvai Event.

Close to the beginning of the Laplace Period, the proportion of species of the benthic foraminiferal genus Dentalina show a marked decrease. A pronounced increase for Nonion sp. is shown at $10.09 \mathrm{~m}$, hence also close to the beginning of the Laplace Period. The Croll Period is characterized by the last occurrence (LO) of the benthic foraminiferal species Pleurostomella brevis, Pleurostomella alternans, and Nodogenerina sagriensis below the Mid-Pleistocene Revolution (MPR). 
The end of the Croll Period and the beginning of the Milankovitch Period is marked by the LO of the benthic foraminiferal species Cibicidoides pseudoungerianus. Slightly below this change in isotopic variability, Fissurina seminifornis occurs for the first time.

The calibration of the planktonic foraminiferal events of core $34 \mathrm{KL}$ is as follows (compare Fig. 12, and Imbrie et al., 1984 and Shackleton et al., 1990):

(1) The FO of Bolliella adamsi is within the topmost sample studied at $0.27-0.30 \mathrm{~m}$. According to Blow (1969) and Saito et al. (1981), this species occurs within the late Quaternary. According to Bolli and Saunders (1985), it is restricted to the Holocene. Chapronière (1991) found this species within either oxygen isotope stage 1 or 2 in the Holocene. According to our data, it occurs close to oxygen isotope event 2.2 at $0.21 \mathrm{~m}$ core depth.

(2) The LO of Globigerinoides ruber/pink was at $0.87-0.90 \mathrm{~m}$ core depth. The next samples above contain only a single specimens of this species which might be reworked. The extinction level of this species is close to oxygen isotope event 5.5 which is at $0.78 \mathrm{~m}$. It agrees with the $0.12 \mathrm{Ma}$ age as reported by Thompson et al. (1979) for the Indian and Pacific Oceans and with data from Chapronière (1991) from the Coral Sea, offshore Queensland, and from the Fiji and Tongan regions (Chapronière, 1985a,b).

(3) The LO of Globorotalia tumida flexuosa is at $1.14-1.16 \mathrm{~m}$ core depth which is close to oxygen isotope event 7.1 at $1.18 \mathrm{~m}$. It is slightly higher than the FO of the calcareous nannofossil Emiliana huxleyi which is between 1.31 and $1.39 \mathrm{~m}$. Chapronière (1991) found Globorotalia tumida flexuosa in the Coral Sea, offshore Queensland, up to oxygen isotope stage 4 .

(4) The LO of Globoquadrina pseudofoliata is at $1.29-1.32 \mathrm{~m}$ core depth and is close to oxygen isotope event 7.3 at $1.28 \mathrm{~m}$. Thompson and Saito (1974) dated first the extinction level of this species at $0.22 \mathrm{Ma}$ in the Indo-Pacific Oceans between $10^{\circ} \mathrm{N}$ and $20^{\circ} \mathrm{S}$.

(5) The FO of Globigerinoides ruber/pink (Plate III) is at $2.58-2.61 \mathrm{~m}$ core depth. Riech (1990) has shown that in the Lau Basin and the North Fiji Basin the FO of Globigerinoides ruber/pink is at about $0.40 \mathrm{Ma}$. The age is con- firmed by our oxygen isotope data. The FO of Globigerinoides ruber/pink is close to oxygen isotope event 11.3 at $2.63 \mathrm{~m}$. The FO of Globigerinoides ruber/pink appears to be strongly diachronous (Chapronière, 1985, 1991; Chapronière and Nishi, 1994).

(6) The LO of Globorotalia tosaensis is at 3.38-3.41 m core depth which coincides with oxygen isotope event 14.2 at $3.38 \mathrm{~m}$. This event dates the top of the Globorotalia truncatulinoides-Globorotalia tosaensis Overlap Zone of Kennett and Srinivasan (1983). According to Thompson and Sciarillo (1978), this event occurs in oxygen isotope stage 15 . The LO of Globorotalia tosaensis was discussed by Chapronière and Nishi (1994). For the Lau Basin area this event was found to be typical of the upper part of the Matuyama Chron, and specimens found within the Brunhes chron were probably reworked. There is certainly a problem with this bioevent which needs further investigations.

(7) and (8) The total range of Globigerinoides gomitulus/pink (Plate III) was found between 4.59-4.62 $\mathrm{m}$ (LO) and 7.78-7.81 $\mathrm{m}$ (FO) core depth. In cores from the Lau Basin and the North Fiji Basin the range of this pink-pigmented variety of Globigerinoides gomitulus was found within an interval from oxygen isotope event $21-22$, dated as about 0.78-0.82 Ma (Von Daniels, 1990); magnetostratigraphically dated cores yielded a mean age of about 0.78-0.86 Ma (Riech, 1990). These previous data are now amended. In core $34 \mathrm{KL}$ the distribution of Globigerinoides gomitulus/pink correlates with the interval between oxygen isotope event 19.1 at $4.68 \mathrm{~m}$ and oxygen isotope event 47 at $7.93 \mathrm{~m}$.

(9) The LO of Globigerinoides fistulosus, as described by Saito et al. (1981), is at 9.14-9.16 m core depth which is close to oxygen isotope event 58 at $9.08 \mathrm{~m}$. The extinction level is above the top of the paleomagnetic Olduvai Event at 9.60-9.70 $\mathrm{m}$. This record agrees well with data from Berggren et al. (1980, 1985) and Chapronière (1991). According to these authors Globigerinoides fistulosus occurs well within the lower part of the Globorotalia truncatulinoides Zone (N 22). According to Shackleton and Hall (1989), the extinction level is close to oxygen isotope event 
61. The top of the Globigerinoides fistulosus Zone, which was believed to indicate the Pliocene/ Pleistocene boundary by Jenkins and Orr (1971), Orr and Jenkins (1972) and Jenkins and Houghton (1989), is significantly younger than the paleomagnetic and calcareous nannofossil Pliocene/ Pleistocene boundary as defined in our core $34 \mathrm{KL}$.

(10) The FO of Beella digitata, evolving from Beella praedigitata (Parker, 1962), is at 9.14-9.16 m core depth and coincides with the LO of Globigerinoides fistulosus close to oxygen isotope events 60/59 (see above). According to Kennett and Srinivasan (1983) Beella digitata occurs close to the base of the Globorotalia truncatulinoides Zone (N 22).

(11) The FO of Globorotalia truncatulinoides was found at $9.37-9.40 \mathrm{~m}$ core depth which is close to oxygen isotope event 61 . The event had been dated as close to the Pliocene/Pleistocene or the N 21/N 22 boundaries, respectively (Bolli and Bermudez, 1965; Bolli, 1966; Blow, 1969). The event has been dated as $1.9 \mathrm{Ma}$ and it was thought to approximate the base of the paleomagnetic Olduvai Event (Berggren et al., 1985). In core $34 \mathrm{KL}$ from the Manihiki Plateau, the FO of Globorotalia truncatulinoides is at about $1.70 \mathrm{Ma}$ and above the top of the Olduvai Event at 9.60-9.70 m. As demonstrated by Dowsett (1989) and Hills and Thierstein (1989), the FO of Globorotalia truncatulinoides is diachronous in lower and higher latitudes of the southern Pacific where it occurs in late Pliocene sediments. The FO of Globorotalia truncatulinoides, therefore, is of low value for both the recognition of the Pliocene/ Pleistocene boundary and the time-equivalent inter-regional or global correlation of the base of the planktonic foraminiferal Globorotalia truncatulinoides Zone (N 22).

Sphaeroidinella dehiscens, a deep water species, decreases significantly at the Brunhes-Matuyama boundary at 5.10-5.20 m, whereas Candeina nitida slightly increases above this boundary. This change in abundances is close to the Mid-Pleistocene Revolution (MPR).

Globigerinoides ruber shows a remarkable drop at about $7.80 \mathrm{~m}$ which is close to oxygen isotope events 46/47). At this interval, Globigerinella aequilateralis, Globigerinoides sacculifer-trilobus Gs. cf. trilobus, Gs. conglobatus and Sphaeroidinella dehiscens show slightly increased abundance values in the upper Laplace Period and later on reduced abundance values at the transition from the Laplace to the Croll periods. From this interval on Globigerinella aequilateralis as well as Globigerinita glutinata abundance is high in general.

There are similar abundance fiuctuations of Globigerinoides ruber, Globigerinoides sacculifer-trilobus, Gs. cf. trilobus and Gs. conglobatus at $15.70 \mathrm{~m}$ near the Matuyama-Gauss boundary and the oxygen isotope event 103 , respectively, and at $1.30 \mathrm{~m}$ which is near the NN 20/NN 21 boundary and close to oxygen isotope event 7.3.

\subsection{Origin of seismic reflectors}

Fig. 4 summarizes the correlation of $3.5 \mathrm{kHz}$ reflectors, lithologic, oxygen isotopic and magnetostratigraphic events and epochs.

Neither sonic velocities were measured in core $34 \mathrm{KL}$, nor in the topmost drilled cores of Site 317. However, if a realistic velocity range of 1500-1550 m/s (e.g., Mienert, 1986; Mosher et al., 1993) is applied, four $3.5 \mathrm{kHz}$ subbottom reflectors produced by $\mathrm{R} / \mathrm{V}$ Sonne lie within the $16 \mathrm{~m}$ depth penetrated by core 34KL (Fig. 3). The strongest reflector $\left(R_{4}\right)$ at $15 \mathrm{~ms}$ correlates with the significant down-core increase of the carbonate content at around $12 \mathrm{~m}$ depth following a strong dip in the $\mathrm{CaCO}_{3}$ curve, as also indicated by a change in sediment color from very pale-brown above to white below. The second strongest reflector $\left(R_{2}\right)$ at $8 \mathrm{~ms}$ may be linked to a further strong oscillation in the carbonate content at $6 \mathrm{~m}$ depth (using a sound velocity of $1500 \mathrm{~m} / \mathrm{s}$ ). This reflector $R_{2}$ lies somewhat deeper than the isotopically defined Mid-Pleistocene Revolution (MPR). However, given the uncertainty in employing exact reflection times, the reflector $R_{2}$ may be used to trace the Mid-Pleistocene Revolution (MPR) regionally. Based on the same sound velocity, the reflector at $6 \mathrm{~ms}\left(\mathrm{R}_{1}\right)$ would occur at $4.50 \mathrm{~m}$ depth, where silica dissolution reaches its final state as indicated by the disappearance of siliceous fossils and the onset of constantly high clinoptilolite values. Hence, the $R_{1}$ reflector may mark a diagenetic boundary. 
The reflector at $12 \mathrm{~ms}\left(\mathrm{R}_{3}\right)$ is difficult to interpret because the low-resolution $\mathrm{CaCO}_{3}$ record shows no major lithologic change at $9.30 \mathrm{~m}$ depth where the reflector would occur at a sound velocity of $1.550 \mathrm{~m} / \mathrm{s}$.

The uniform character of the seismic record for most parts of the High Plateau, where reflectors $R_{1}, R_{2}$, and $R_{4}$ are linked to well defined changes in lithology, supports tracing the stratigraphic sequence of core $34 \mathrm{KL}$ over large portions of this region as far as to the eroded edge of the plateau in the east and northeast of location 34KL (e.g., see Beiersdorf and Erzinger, 1989). Here the sequence can be tied to outcropping Neogene sequences of lower stratigraphic levels.

\section{Summary and conclusions}

Because of its position well above the calcite compensation depth (CCD) and the apparent lack of hiatuses, core location 34KL at the High Plateau of the Manihiki Plateau forms a promising site for comparative stratigraphic studies of PleistocenePliocene sediments from a tropical to subtropical environment. The $16 \mathrm{~m}$ long core $34 \mathrm{KL}$ provides a well preserved parallel section of the heavily disturbed Pleistocene-Late Pliocene section of DSDP Hole 317, drilled in 1973. The virtually undisturbed core $34 \mathrm{KL}$ allows an intercalibration of magneto-, isotope- and biostratigraphic records over the last $2.6 \mathrm{Ma}$, although sedimentation rates are low (average $0.61 \mathrm{~cm} / \mathrm{kyr}$ ).

The lack of calcite dissolution has prevented the sediments from compacting, hence magnetosomes remained in place and un-rotated. This undisturbed fabric, in turn, allowed us to achieve a highly accurate magnetostratigraphic record despite the low intensity of the natural remanent magnetization (NRM). Both the BrunhesMatuyama and Matuyama-Gauss boundaries as well as the Olduvai magnetic event were clearly identified. The lower boundary of the Jaramillo event is somewhat uncertain.

The low sedimentation rates result from low primary productivity at a location far distant from the highly productive equatorial upwelling zone.

In the oxygen isotope record of core $34 \mathrm{KL}$, the
Milankovitch (100 kyr-cycle dominance) and Laplace (41 kyr-cycle dominance) periods of Berger and Wefer (1992) are clearly recognized, but the transitional Croll Period is less well recorded. The Mid-Pleistocene Revolution (MPR) is clearly recorded at oxygen isotope event boundary $22 / 23$, slightly below the paleomagnetic Brunhes-Matuyama boundary, and possibly biased by a hiatus.

The Pliocene/Pleistocene boundary is defined precisely by the last occurrence of calcareous nannofossil Discoaster brouweri. It occurs in the lowest part of the paleomagnetic Olduvai Event, and largely coincides with both the beginning of the Laplace Period (after Berger and Wefer, 1992) and a drop in average sedimentation rates from 8.7 to $5.4 \mathrm{~m} / \mathrm{Myr}$.

All important calcareous microfossil zones of the last 2.6 Myr were identified. The high degree of silica dissolution below $3 \mathrm{~m}$ permitted us to define a single siliceous fossil zone only, i.e. the Buccinosphaera invaginata (radiolarian) Zone. The lack of any significant calcite dissolution suggests that fluctuations in calcareous microfossil associations reflect productivity changes only, which parallel, to some extent, orbital changes of climate, as recorded in the $\delta^{18} 0$ curve.

Two biostratigraphic zones for both benthic and planktonic foraminifers were established for the last 2.6 Ma. The benthic Fissurina seminiformis (partial range) Zone starts at about $0.742 \mathrm{Ma}$ (oxygen isotope event 18). The planktonic Globorotalia truncatulinoides Zone starts at about $1.70 \mathrm{Ma}$, slightly above the top of the Olduvai Event, near oxygen isotope event 61 , whereas the Globorotalia tosaensis Zone was found below. The occurrence of Globigerinoides gomitulus/pink, the second "pink marker" after Globigerinoides ruber/pink, in core $34 \mathrm{KL}$ between oxygen isotope events 19.1 and 47 hints at a greater stratigraphic and geographic range of this species, which was known before only from the Lau and the North Fiji basins. Four benthic species became extinct between oxygen isotope events 36 and 16 , one had its first occurrence. Therefore, even with a clearly visible Mid-Pleistocene Revolution (MPR), in our core a transitional Croll Period seems to be reflected in the foraminiferal record. The beginning 
of the Laplace Period is closely related to significant abundance changes for Nonion and Dentalina species.

The complete dissolution of silica below $4 \mathrm{~m}$ has favoured the authigenic formation of clinoptilolite. Changes in clinoptilolite and calcium carbonate concentrations probably cause the upper four $3.5-\mathrm{kHz}$ subbottom reflectors. These changes are now calibrated on magnetostratigraphic, oxygen-isotopestratigraphic, and biostratigraphic scales. The prominent subbottom reflector $R_{2}$ marks a pronounced oscillation in the calcium carbonate curve in the Croll Period. Reflector $\mathbf{R}_{4}$ marks another extreme low in the carbonate curve and parallels a significant change in sediment color. It also may parallel the transition from the PreLaplace to the Laplace periods. Both reflectors can be traced over large parts of the Manihiki Plateau indicating that little or no erosion and redistribution has affected the sediments which were deposited during the last $2.6 \mathrm{Ma}$. This is supported by the apparent lack of reworked fossils. In summary, core $34 \mathrm{KL}$ provides a significant record of information for a better correlation of magnetostratigraphic, oxygen isotope stratigraphic, and biostratigraphic events. The sequence of events can be traced further northeast in $3.5-\mathrm{kHz}$ records up to the eroded northeastern edge of the Manihiki Plateau where it can be tied to outcropping older Neogene sequences. These outcrops may provide a further opportunity for detailed high-resolution stratigraphic studies of the older sediment sections based on shallow gravity or piston coring.

\section{Acknowledgements}

We thank the shipboard party of $\mathrm{R} / \mathrm{V}$ Sonne cruise SO67-1 for assistance in sampling and other help rendered during the cruise. We are indebted to $\mathrm{Ch}$. Hemleben (Tübingen) and M. Sarnthein (Kiel) for their constructive comments on the draft manuscript. Our special thanks go to W.H. Berger and G.C. Chapronière who critically reviewed the manuscript and provided useful suggestions for its improvement. We also thank A. Bruns, E. Bitzer, G. Bulla, R. Engel, and
H. Karmann (all BGR), who took care of REM photographs, typing of the manuscript and drawings. The Bundesministerium für Forschung und Technologie (Germany) provided the funding of the cruise, we thankfully acknowledge this support.

We thank the Government of the Cook Islands for granting permission to work in their Exclusive Economic Zone and for providing the assistance of A. Utanga in the shipboard work. The South Pacific Applied Geoscience Commission helped considerably to launch the cruise. Therefore, our special thanks go to them.

\section{References}

Archer, O.E., 1991. Equatorial Pacific calcite preservation cycles: Production or dissolution? Paleoceanography, 6(5): 561-571.

Baksi, A.K., Hsu, U., McWilliams, M.O. and Farrar, E., 1992. ${ }^{40} \mathrm{Ar} /{ }^{39} \mathrm{Ar}$ dating of the Brunhes-Matuyama geomagnetic field reversal. Science, 256: 356-357.

Battarbee, R.W., 1973. A new method for the estimation of absolute microfossil numbers, with reference especially to diatoms. Limnol. Oceanogr., 18: 647-653.

Bé, A.W.H., 1977. An ecological, zoogeographical and taxonomic review of Recent planktonic foraminifera. In: A.T.N. Ramsay (Editor), Oceanic Micropaleontology. Academic Press, London, 1: 1-88.

Beiersdorf, H, and Erzinger, J., 1989. Observations on the bathymetry and geology of the northeastern Manihiki Plateau, southwestern Pacific Ocean. CCOP/SOPAC S. Pac. Mar. Geol. Notes, 3, 4: 33-46.

Belyaeva, T.V., 1970. Taxonomy and distribution patterns of plankton diatoms in the equatorial Pacific. Okeanologiya, 10: 132-139, and Oceanology, 10; 101-107 (Engl. translation).

Belyaeva, T.V., 1971. Quantitative distribution of planktonic diatoms in the western tropical Pacific. Okeanologiya, 11: 687-694, and Oceanology 11: 578-585 (Engl. translation).

Berger, W.H., Fischer, K., Lai, C. and Wu, G., 1987. Ocean productivity and organic carbon flux. Part I, Overview and maps of primary production and export production. Univ. Calif., San Diego, SIO Ref., 87-30: 1-67.

Berger, W.H. and Wefer, G., 1992. Klimageschichte aus Tiefseesedimenten: Neues vom Ontong Java Plateau (Westpazifik). Naturwissenschaften, 79: 541-550.

Berger, W.H., Bickert, T., Schmidt, H. and Wefer, G., 1993a. Quaternary oxygen isotope record of pelagic foraminifers: Site 806, Ontong Java Plateau. Proc. ODP, Sci. Results, 130: 381-395.

Berger, W.H., Leckie, R.M., Janecek, T.R., Stax, R. and Takayama, T., 1993b. Neogene carbonate sedimentation on 
Ontong Java Plateau: Highlights and open questions. Proc. ODP, Sci. Results, 130: 711-744.

Berggren, W.A., Burckle, L.H., Cita, M.B., Cooke, H.B.S., Funnell, B.M., Gartner, S., Hays, J.D., Kennett, J.P., Opdyke, N.D., Pastouret, L., Shackleton, N.J. and Takayanagi, Y., 1980. Towards a Quaternary time scale. Quat. Res., 13: 277-302.

Berggren, W.A., Kent, D.V. and Van Couvering, J.A., 1985. The Neogenc: Part 2. Ncogene geochronology and chronostratigraphy. In: N.J. Snelling (Editor), The Chronology of the Geological Record. Geol. Soc. London Mem., 10: 211-260.

Bickert, T., Berger, W.H., Burke, S., Schmidt, H. and Wefer, G., 1993. Late Quaternary stable isotope record of benthic foraminifera at sites 805 and 806, Ontong Java Plateau. Proc. ODP, Sci. Results, 130: 411-420.

Bjørklund, K.R. and Goll, R.M., 1979. Internal skeletal structures of Collosphaera and Trisolenia: A case of repetitive evolution in the Collosphaeridae (Radiolaria). J. Paleontol., 53: $1293-1326$.

Blow, W.H., 1969. Late middle Eocene to Recent planktonic foraminiferal biostratigraphy. In: P. Brönnimann and H.H. Renz (Editors), Proc. 1st Int. Conf. Planktonic Microfossils. (Geneva, 1967.) Cambridge Univ. Press, Cambridge, 1: 199-422.

Bolli, H.M., 1966. Zonation of Cretaceous to Pliocene marine sediments based on planktonic foraminifera. Bol. Inform. Asoc. Venezolana Geol., Mineria, Petrol., 9(1): 3-32.

Bolli, H.M. and Bermudez, P.J., 1965. Zonation based on planktonic foraminifera of Middle Miocene to Pliocene warm-water sediments. Bol. Inform. Asoc. Venezolana Geol., Mineria, Petrol., 8(5): 119-149.

Bolli, H.M. and Saunders, J.B., 1985. Oligocene to Holocene low latitude planktic foraminifera. In: H.M. Bolli, J.B. Saunders and K. Perch-Nielsen (Editors), Plankton Stratigraphy. Cambridge University Press, Cambridge, pp. $155-262$.

Boyce, R.E., 1976. Definitions and laboratory techniques of compressional sound velocity parameters and wet-water content, wet bulk density, and porosity parameters by gravimetric and gamma ray attenuation techniques. Init. Rep. DSDP, 33: 931-958.

Burckle, L.H., 1972. Late Cenozoic planktonic diatom zones from the eastern equatorial Pacific. Nova Hedwigia, 39: 217-246.

Burckle, L.H., 1977. Pliocene and Pleistocene diatom datum levels from the equatorial Pacific. Quat. Res., 7: 330-340.

Burke, S.K., Berger, W.H., Coulbourn, W.T. and Vincent, E., 1993. Benthic foraminifera from Box Core ERDC 112 , Ontong Java Plateau. J. Foraminiferal Res., 23: 19-39.

Cande, S.C. and Kent, D.V., 1992. A new geomagnetic polarity time scale for the Late Cretaceous and Cenozoic. J. Geophys. Res., 97(B10): 13,917-13,951.

Cepek, P., 1981. Kalzitisches Nannoplankton. In: F. Bender (Editor). Angewandte Geowissenschaften, 1: 407-414.

Chappel, J. and Shackleton, N.J., 1986. Oxygen isotopes and sea-level. Nature, 324: 137-140.
Chapronière, G.C.H., 1985a. Late Neogene and Quaternary planktonic foraminiferal biostratigraphy and paleobathymetry of dredge samples from the southern Tongan Platform (Cruise L5-82-SP). In: D.W. Scholl and T.L. Vallier (Editors), Geology and Offshore Resources of Pacific Island Arcs-Tonga Region. Circum-Pac. Counc. Energy Miner. Resour. Earth Sci. Ser., 2: 131-140.

Chapronière, G.C.H., 1985b. Late Tertiary and Quaternary foraminiferal biostratigraphy and paleobathymetry of cores and dredge samples from Cruise KK820316 Leg 2. In: T.M. Brocher (Editor), Geological Investigation of the Northern Melanesian Borderland. Circum-Pac. Counc. Energy Mineral Resour. Earth Sci. Ser., 3: 103-122.

Chapronière, G.C.H., 1991. Pleistocene to Holocene planktic foraminiferal biostratigraphy of the Coral Sea, offshore Queensland, Australia. BMR J. Austr. Geol. Geophys., 12(3): 195221.

Chapronière, G.C.H. and Nishi, H., 1994. Miocene to Pleistocene planktonic foraminifer biostratigraphy of the Lau Basin and Tongan Platform, Leg 135. Proc. ODP, Sci. Results, 135: 207-229.

Couture, R., Müller, R.S. and Gieskes, J.M., 1978. Interstitial water and mineralogical studies, Leg 41. Init. Rep. DSDP, 41: 907-914.

Dowsett, H.J., 1989. Application of the graphic correlation method to Pliocene marine sequences. Mar. Micropaleontol., 14: 3-32.

Fairbanks, R.G., 1989. A 17.000-year glacio-eustatic sea level record: Influence of glacial melting rates on the Younger Dryas event and deep-ocean circulation. Nature, 342: $637-642$.

Fenner, J., 1982. Diatoms in the Eocene and Oligocene sediments off NWAfrica, their stratigraphic and paleogeographic occurrences. Ph.D. Thesis, Univ. Kiel, $230 \mathrm{pp}$.

Fenner, J., 1985. Late Cretaceous to Oligocene planktic diatoms. In: H.M. Bolli, J.B. Saunders and K. Perch-Nielsen (Editors), Plankton Stratigraphy. Cambridge Univ. Press, Cambridge, pp. 713-762.

Hay, W.W., 1965. Calcareous Nannofossils. In: B. Kummel and D. Raup, Handbook of Paleontological Techniques. pp. 3-7.

Hays, J.D., 1970. Stratigraphy and evolutionary trends of Radiolaria in North Pacific deep-sea sediments. In: J.D. Ilays (Editor), Geological Investigations of the North Pacific. Geol. Soc. Am. Mem., 126: 185-218.

Hays, J.D., Saito, T., Opdyke, N.D. and Burckle, L.H., 1969. PliocenePleistocene sediments of the equatorial Pacific: Their paleomagnetic, biostratigraphic, and climatic record. Geol. Soc. Am. Bull., 80: 1481-1514.

Hays, J.D. and Shackleton, N.J., 1976. Globally synchronous extinction of the radiolarian Stylatractus universus. Geology, 4: 649652 .

Heezen, B.C. and Hollister, C.D., 1971. The face of the Deep. Oxford Univ. Press, Oxford, 659 p.

Hills, S.J. and Thierstein, H.R., 1989. Plio-Pleistocene calcareous plankton biochronology. Mar. Micropaleontol., 14: 67-96. 
Hussong, D.M., Wipperman, L.K. and Kroenke, L.W., 1979. The crustal structure of the Ontong Java and Manihiki oceanic plateaus. J. Geophys. Res., 84(B11): 6003-6010.

Imbrie, J., Hays, J.D., Martinson, D.G., McIntyre, A., Mix, A.C., Morley, J.J., Pisias, N.G., Prell, W.L. and Shackleton, N.J., 1984. The orbital theory of Pleistocene climate: Support from a revised chronology of the marine $\delta^{18} 0$ record. In: A.L. Berger et al. (Editors), Milankovitch and Climate. Kluwer, Dordrecht, I: 269-305.

Ingle, J.C., Keller, G. and Kolpack, R.L., 1980. Benthic foraminiferal biofacies, sediments and water masses of the southern Peru-Chile Trench area, southeastern Pacific Ocean. Micropaleontology, 26(2): 113-150.

Izett, G.A. and Obradovich, J.D., 1991. Dating of the Matuyama-Brunhes boundary based on ${ }^{40} \mathrm{Ar}-{ }^{39} \mathrm{Ar}$ ages of the Bishop Tuff and Cerro San Luis rhyolite. Geol. Soc. Am., Abstr. Progr., 23: A106.

Jenkins, D.G. and Orr, W.N., 1971. Cenozoic planktonic foraminiferal zonation and the problem of test solution. Revista Espan. Micropaleontology, 3 (3): 301-304.

Jenkins, D.G. and Houghton, S.D., 1989. Late Miocene to Pleistocene planktonic foraminifers from Ocean Drilling Program Site 677, Panama Basin. Proc. ODP, Sci. Results, 111: 289-293.

Johnson, D.A., Schneider, D.A., Nigrini, C.A., Caulet, J.P. and Kent, D.V., 1989. Pliocene-Pleistocene Radiolarian Events and Magnetostratigraphic Calibrations for the Tropical Indian Ocean. Mar. Micropaleontol, 14: 33-66.

Jousé, A.P., Kozlova, O.G. and Mukhina, V.V., 1971. Distribution of diatoms in the surface layer of sediment from the Pacific Ocean. In: B.M. Funnel and W.R. Riedel (Editors), Micropaleontology of the Oceans. Academic Press, New York, pp. 263-269.

Kastner, M. and Stonecipher, S.A., 1978. Zeolites in pelagic sediments of the Atlantic, Pacific, and Indian Oceans. In: L.B. Sand and F.A. Mumpton (Editors), Natural Zeolites. New York, Pergamon, pp. 199-230.

Kenuett, J.P. and Srinivasan, M.S., 1983. Neogene Planktonic Foraminifera. A Phylogenetic Atlas. Hutchinson and Ross, Stroudsburg, PA, 265 pp.

Knoll, A.H. and Johnson, D.A,, 1975. Late Pleistocene evolution of the collosphaerid radiolarian Buccinosphaera invaginata Haeckel. Micropaleontology, 21: 60-68.

Kolbe, R.W., 1957. Diatoms from equatorial Indian Ocean cores. Rep. Swed. Deep Sea Exped. 1947-1948, 9: 1-50.

Lanphyre, M.A. and Dalrymple, G.B., 1976. K-Ar ages of basalts from DSDP Leg 33: Sites 315 (Line Islands) and 317 (Manihiki Plateau). Init. Rep. DSDP, 33: 649-653.

Lohmann, G.P., 1978. Abyssal benthonic foraminifera as hydrologic indicators in the Western South Atlantic Ocean. J. Foraminiferal Res., 8 (1): 6-34.

Lutze, G.-F. and Coulbourn, W.T., 1984. Recent benthic Foraminifera from the continental margin of northwest Africa: community structures and distribution. Mar. Micropaleontol., 8: 361-401.

Martini, E. and Müller, C., 1986. Current Tertiary and
Quaternary calcareous nannoplankton stratigraphy and correlations. Newsl. Stratigr., 16: 99-112.

Mayer, L., Pisias, N., Janecek, T. and Shipboard Scientific Party, ODP Leg 138, 1992. High-resolution studies of the eastern equatorial Pacific. EOS, Am. Geophys. Union, 73: $257-262$.

Mienert, J., 1986. Akustostratigraphie im äquatorialen Ostatiantik: Zur Entwicklung der Tiefenwasserzirkulation der letzten 3,5 Millionen Jahre. Meteor Forsch. Ergebn., Reihe C, 40: 19-86.

Mix, A.C., 1987. The oxygen-isotope record of glaciation. In: W.F. Kuddiman and H.E. Wright (Editors), North America and Adjacent Oceans during the Last Deglaciation. (The Geology of North America, K-3.) Geol. Soc. Am., Boulder, CO, pp. 111-135.

Morley, J.J. and Shackleton, N.J., 1978. Extenxion of the radiolarian Stylatractus universus as a biostratigraphic datum to the Atlantic Ocean. Geology, 6: 309-311.

Mosher, D.C., Mayer, L.A., Shipley, T.H., Winterer, E.L., Hagen, R.A., Masters, J.C., Bassinot, F., Wilkens, R.H. and Lyle, M., 1993. Seismic stratigraphy of the Ontong Java Plateau. Proc. ODP, Sci. Results, 130: 33-49.

Nigrini, C., 1971. Radiolarian zones in the Quaternary of the equatorial Pacific Ocean. In: B.M. Funnell and W.R. Riedel (Editors), The Micropaleontology of Oceans. Cambridge Univ. Press, Cambridge, pp. 443 461 .

Orr, W.N. and Jenkins, O.G., 1972. Eastern equatorial Pacific Pliocene-Pleistocene biostratigraphy. Cushman Found. Spec. Publ., 19: 278-286.

Parker, F.L., 1962. Planktonic foraminiferal species in Pacific sediments. Micropaleontology, 8(2): 219-254.

Parker, F.L., 1967. Tertiary biostratigraphy (planktonic Foraminifera) of tropical Indo-Pacific deep-sea cores. Am. Paleontol. Bull., 52(235): 115-208.

Resig, J.M., 1981. Biogeography of benthic foraminifera of the northern Nazca plate and adjacent continental margin. Geol. Soc. Am. Mem., 154: 619-665.

Riech, V., 1984. Calcareous ooze, volcanic ash, and metalliferous sediments in the Quaternary of the Lau and North Fiji Basins. Geol. Jahrb., Reihe D, 92: 109-162.

Ruddiman, W.F., Raymo, M.E., Martinson, D.G., Clement, B.M. and Backman, J., 1989. Pleistocene evolution: Northern Hemisphere ice sheets and North Atlantic Ocean. Paleoceanography, 4: 353412.

Saito, T., Thompson, P.R. and Breger, D., 1981. Systematic Index of Recent to Pleistocene Planktonic Foraminifera. Univ. Tokyo Press, Tokyo, 190 pp.

Schlanger, S.O., Jackson E.D., et al., 1976. Site 317. Init. Rep. DSDP, 33: 161-300.

Schlanger, S.O. and Winterer, E.L., 1976. Underway geophysical data: navigation bathymetry, magnetics, and seismic profiles. Init. Rep. DSDP, 33: 655-693.

Schmidt, H., Berger, W.H., Bickert, T. and Wefer, G., 1993. Quaternary carbon isotope record of pelagic foraminifers: Site 806, Ontong Java Plateau. Proc. ODP, Sci. Results, 130: 397-409.

Shackleton, J.N. and Hall, M.A., 1989. Stable isotope history 
of the Pleistocene at ODP Site 677. Proc. ODP, Sci. Results., 111: 295-316.

Shackleton, N.J., Berger, A. and Peltier, W.R., 1990. An alternative astronomical calibration of the lower Pleistocene timescale based on ODP Site 677. Trans. R. Soc. Edinburgh, Earth Sci., 81: 251-261.

Tiedemann, R., Sarnthein, M. and Shackleton, N.J., 1994. Astronomic timescale for the Pliocene Atlantic $\delta^{18} 0$ and dust flux records of ODP Site 659. Paleoceanography, in press.

Thompson, P.R. and Saito, T., 1974. Pacific Pleistocene sediments: Dissolution cycles and geochronology. Geology, 2(7): 333-335.

Thompson, P.R. and Sciarillo, J.R., 1978. Planktonic foraminiferal biostratigraphy in the Equatorial Pacific. Nature, 276(5683): 29-33.

Thompson, P.R., Bé, A.W.H., Duplessy, J.-C. and Shackleton, N.J., 1979. Disappearance of pink-pigmented Globigerinoides ruber at 120,000 yr BP in the Indian and Pacific Oceans. Nature, 280 (5723): 554-558.

Vali, H., Förster, O., Amarantidis, G. and Petersen, N., 1987. Magnetotactic bacteria and their magnetofossils in sediments. Earth Planet. Sci. Lett., 86: 389-400.

Van Andel, T.H., Heath, G.R. and Moore, T.C., 1975. Cenozoic Rates of Deposition. In: Cenozoic History and Paleoceanography of the Central Equatorial Pacific Ocean. Geol. Soc. Am. Mem., 143: 49-72.

Von Daniels, C.H., 1990. Foraminifera and oxygen isotope stratigraphy in a core from the Lau Basin, southwest Pacific Ocean. Geol. Jahrb., Reihe D, 92: 209-229.

Von Dobeneck, T., 1992. Neue Ansätze zur Messung und Interpretation der magnetischen Hysterese von Tiefseesedimenten. $\mathrm{Ph} . \mathrm{D}$. Thesis, Univ. Munich.

Wiedenmayer, F., 1977. Shallow-water Sponges of the Western Bahamas. Birkhäuser, Basel, 297 pp. 